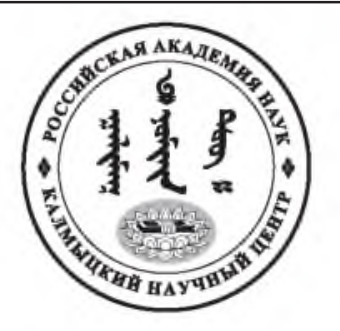

Published in the Russian Federation

Oriental Studies (Previous Name: Bulletin of the Kalmyk Institute

for Humanities of the Russian Academy of Sciences)

Has been issued as a journal since 2008

ISSN: 2619-0990; E-ISSN: 2619-1008

Vol. 14, Is. 2, pp. 314-336, 2021

Journal homepage: https://kigiran.elpub.ru

УДК / UDC 39

DOI: $10.22162 / 2619-0990-2021-54-2-314-336$

\title{
Особенности иконографии в калмыцкой вышивке: традиционные и современные практики
}

\section{Татьяна Исаевна Шараева}

\author{
${ }^{1}$ Калмыцкий научный центр РАН (д. 8, ул. И. К. Илишкина, 358000 Элиста, Российская \\ Федерация) \\ кандидат исторических наук. старший научный сотрудник \\ (D) 0000-0002-2242-5136. E-mail: sharaevati $a$ yandex.ru \\ (C) КалмНЦ РАН, 2021 \\ (C) Шараева Т. К., 2021
}

Аннотация. Введение. Калмыки, монголоязычный народ. пришедший в степи Поволжья в XVII в. из Центральной Азии, исповедуют буддизм. Этноспецифические черты буддизма калмыков, сформировавшиеся за время пребывания на территории России, обусловлены различными историческими факторами. в том числе длительной отдаленностью от буддийских центров, ликвидацией буддийских храмов и объединений на протяжении десятилетий в ХХ в. и официальным восстановлением в конце XX- начале XXI в. Целью работы является выделение и сопоставление традиционных и современных буддийских танка как отражающих особенности калмыцкой иконографин, значимых предметов религиозного культа и культурного наследия калмыков. Результаmbl. Выявлено, что вплоть до начала ХХ в. у калмыков практиковалось изготовление танка в различных техниках — живописные, вышитые и аппликативные. С конце XVIII в., в связи с ограничением ввоза культовых предметов из Тибета и Монголни, увеличилось значение мастерских при калмыцких буддийских храмах. Это послужило также развитию школ танкописи и формированию этнического стиля в изображении божеств буддийского пантеона, обусловленного некоторым отхождением от традиционного канона. Старинные танка, сохраненные в частных коллекциях и музейных фондах, стали основой для восстановления традиций изобразительного искусства в процессе возрождения буддизма в Калмыкии. Современные практики изготовления изображений божеств связаны с этапами развития буддизма в республике с конца XX в. по настоящее время, мирской формой буддийских практик, женским досугом и этническим предпринимательством. Исследование показало, что современные калмычки-мастерицы руководствуются традиционными правилами изготовления предметов религиозного культа.

К.лючевые слова: калмыки, буддизм, божества, иконография, танка, вышивка

Б.лагодарность. Исследование выполнено при финансовой поддержке гранта в форме субсидии из федерального бюджета, выделяемой для государственной поддержки научных исследований, проводимых под руководством ведущего ученого (проект № 075-15-2019-1879 
«От палеогенетики до культурной антропологии: комплексное интердисциплинарное исследование традиций народов трансграничных регионов: миграции, межкультурное взаимодействие и картина мира»).

Для цитировашия: Шараева Т. И. Особенности иконографии в калмыцкой вышивке: традиционные и современные практики // Oriental Studies. 2021. T. 14. № 2. С. 314-336. DOI: $10.22162 / 2619-0990-2021-54-2-314-336$

\title{
Iconographic Features of Kalmyk Embroidery: Traditional and Contemporary Practices
}

\author{
Tatyana I. Sharaeva
}

\author{
Kalmyk Scientific Center of the RAS (8, Ilishkin St., Elista 358000, Russian Federation) \\ Cand. Sc. (History), Senior Research Associate \\ 0000-0002-2242-5136. E-mail: sharaevatiayandex.ru
}

\author{
(C) KalmSC RAS, 2021 \\ (C) Sharaeva T. I., 2021
}

\begin{abstract}
Introduction. The Kalmyks are a Mongolic Buddhist people that arrived in the Volga region in the $17^{\text {th }}$ century. The specific ethnic features of Buddhism professed by the Kalmyks took shape over centuries of Russian suzerainty and were determined by various historical factors, including prolonged remoteness from Buddhist centers, the total eradication of Buddhist monasteries and centuries-long ban on spiritual guidance experienced in the $20^{\text {th }}$ century, and the official Buddhist restoration by the early $21^{\text {st }}$ century. Goals. The work aims at identifying and comparing traditional and contemporary Buddhist thangka patterns as elements to mirror particular features of Kalmyk iconography, as essential objects of religious cult and cultural heritage at large. Results. The paper shows that in the pre- $20^{\text {th }}$ century period Kalmyks used different techniques for producing thangkas painting, embroidery, and applique ones. In the late $18^{\text {th }}$ century onwards, imports of religious attributes from Tibet and Mongolia were restricted, and the role of art workshops affiliated to local Buddhist temples increased. That resulted in further development of thangka painting schools and the shaping of somewhat ethnic style in depicting Buddhist deities characterized by certain differences from canonical images. The old thangkas from private and public collections have served a basis for the restoration of ethnic painting traditions integral to Kalmykia's Buddhism proper. The contemporary practices of producing divine images are closely related to stages in the regional development of Buddhism from the late $20^{\text {th }}$ century to the present, lay Buddhist experiences, women's leisure-time activities, and ethnic entrepreneurship. The study concludes contemporary Kalmyk needlewomen are guided by traditional rules of religious craftsmanship.

Keywords: Kalmyks, Buddhism, deities, iconography, thangka, embroidery

Acknowledgements. The reported study was funded by government grant in the form of federal budget subsidy aimed to support scientific research directed by the Leading Scientist — project name 'From Paleogenetics to Cultural Anthropology: Comprehensive Interdisciplinary Research of Peoples and Traditions of Cross-Border Regions - Migrations, Cross-Cultural Interactions and Worldviews' (no. 075-15-2019-1879).

For citation: Sharaeva T. I. Iconographic Features of Kalmyk Embroidery: Traditional and Contemporary Practices. Oriental Studies. 2021. Vol. 14 (2): 314-336. (In Russ.). DOI: 10.22162/26190990-2021-54-2-314-336
\end{abstract}

\section{Введение}

«Единственный народ в Европе, исповедующий буддизм», «европейские буддисты» - так часто характеризуют калмыков, и, начиная с 90-х гг. XX в., стали позиционировать себя и калмыки. Эти определения служат «визитными карточками» Калмыкии во многих туристических путеводите- 
лях, в которых представлена информация о различных достопримечательностях республики, большинство из которых в разной степени отражают приверженность местных жителей буддизму [Туристический путеводитель; Монгуш 2015; Шараева 2017б; и др.].

«Я — калмык, значит я - буддист» один из аспектов самоопределения и самосознания у калмыков, ставший и одним из этнических маркеров у калмыков с начала 2000-х гг. на волне процессов этнокультурного возрождения у народов на всем постсоветском пространстве.

История распространения буддизма у калмыков тесно связана со всеми историческими событиями в жизни народа. К моменту прихода в XVII в. этнических предков калмыков - ойратов из Центральной Азии в степи Поволжья буддизм как религия уже получил широкое распространение в их среде [Дорджиева 1995; Бакаева 1994].

В 1640 г. на съезде ойратских и монгольских князей и духовенства буддизм был объявлен государственной религией. Принятые положения «Ик Цааджин бичиг» («Великий кодекс законов», известный в литературе как «Степное уложение»), позднее дополненные различными указами калмыцких ханов [Монголо-ойратские законы 1880], послужили основой укрепления позиций буддизма среди калмыков, ставшего идеологической составляющей их государственности [Курапов 2018].

C XVII в. и до начала XX в. сформировались этноспецифические черты буддизма среди калмыков, в которых исследователи выделяют: «определенный консерватизм, сочетавшийся с возникавшими в силу ряда причин нововведениями; существование традиций различных школ при господствующем положении Гелугпа; прямые связи с Тибетом в XVII - второй трети XVIII в.; полный контроль со стороны царской администрации в XIX - начале XX в.; деление хурулов на большие и малые, зависимость от формализованной отчетности; ограниченная структура должностной иерархии хурулов; наличие у храмов крепостных шабинеров; отсутствие института перерожденчества) [Бакаева 2009: 13-14].

Насыщенный различными историческими событиями $\mathrm{XX}$ в. значительно отразился на буддизме в Калмыкии: в конце 1930-х гг. буддийская церковь была официально ликвидирована (храмы и религиозные объединения закрыты, священнослужители репрессированы либо им пришлось снять сан), а мирская форма буддизма стала латентной, сохранившись в таком виде вплоть до конца XX в.

В развитии буддизма среди калмыков с конца XX в. по настоящее время исследователи выделяют несколько условных этапов: 1988-1992 гг., 1992-1995 гг., 1995-2002 гг., и с 2002 по настоящее время [История буддизма 2011: 69-105].

Разграничение на данные этапы обусловлено теми событиями, которые происходили на небольшом временном отрезке, но по значимости были очередным импульсом в процессах бурного развития «возрожденного» буддизма в Калмыкии.

В 1991 г. в стенах Национального музея Республики Калмыкия им. Н. Н. Пальмова впервые экспонировалась танка ${ }^{1}$ «Зеленая Тара» из фондов Ставропольского государственного объединенного краеведческого музея им. Г. К. Праве. За период нахождения танки на территории Калмыкии ее посетили десятки тысяч местных жителей, для которых в тот период она стала символом начавшихся перемен. По своей значимости и силе воздействия данная выставка в тот период уступала лишь приезду Его Святейшества Далай-ламы XIV, осуществленному впервые в 1991 г., и приезду духовных лидеров буддизма и учителей в республику, ознаменовав начало перемен в религиозной жизни калмыцкого общества. На значение танки «Зеленая Тара» как одного из символов буддизма и культового наследия калмыков указывают также повторные ее экспозиции кратковременная в 2017 г. и годичная в 2020 г. [Буддийскую святыню 2019].

Гораздо позднее, в 2014 г., в Элисте была открыта выставка коллекции культовых предметов из фондов Государственной

1 Танка (тиб.) - в тибетской буддийской традиции изображение религиозного характера, имеющее форму свитка и выполненное на ткани, преимущественно минеральными красками на клеевой основе, либо отпечатанное на ткани. Танка создаются в соответствии с иконографическими канонами. Среди калмыков получила распространение традиция выполнения танка (называемых по-калмыцки дарчг) в технике аппликации, а также в технике вышивки. 
классической академии им. Маймонида, большую часть которой составляли древние калмыцкие манка. Чтобы познакомиться с наследием предков, приезжали многие калмыки, проживавшие далеко за пределами республики [Эрендженова 2014].

В 2016 г. накануне национального весеннего праздника Цаган Сар в центральном хуруле Республики Калмыкия «Золотая обитель Будды Шакьямуни» была открыта выставка «Старинные танки - наследие наших предков»). На ней были представлены 38 танок, которые в течение 10 лет миряне приносили настоятелю храма Анджа-гелюнгу для реставрации и сохранения, осознавая ценность культового предмета и его значимость для калмыцкой культуры в целом [Выставка 2016].

В феврале 2020 г. в главном храме Калмыкии была открыта выставка «15 чудес Будды Шакьямуни», на которой было экспонировано 42 танка с сюжетами о деяниях Будды Шакьямуни, и 15 maнка, знакомивших с жизнью и деятельностью великого учителя ламы Цзонкапы. Все они были переданы в дар центральному хурулу Калмыкии от администрации Его Святейшества Далай-ламы XIV [Открытие выставки 2020].

В марте 2020 г. в Национальном музее Республики Калмыкия им. Н. Н. Пальмова открылась также выставка старинных буддийских манка с изображением Пяти Дхьяни Будд, хранившихся в начале $\mathrm{XX}$ в. в резиденции Богдо-гегяна в Монголии.

Последовательность и наполняемость выставок танка в республике, а также восприятие их калмыками отражают процессы развития буддизма в Калмыкии в начале XXI в.: первоначально на выставки ходили познакомиться с сохранившимися реликвиями, в последующем - уже изучали различные аспекты канонов и практик, специфику калмыцкого буддизма, сейчас же «эти священные изображения были не просто установлены здесь на стендах, а согласно традиции приглашены для выставки - как живые одухотворенные образы» [Выставка $2016]$.

\section{Калмыцкие дарцг: традиции изготов- ления}

В религиозном искусстве тибетского буддизма термин манка ('свиток') обозна- чает изображение религиозного содержания, выполненное клеевыми красками или отпечатанное на шелке или хлопчатобумажной ткани, предварительно загрунтованной смесью из мела и животного клея, квадратной или прямоугольной формы. Объектами изображения на танка являются Будда Шакьямуни и божества буддийского пантеона, житийные циклы и сюжеты бардо [Огнева 1992: 237].

Согласно традиции тибетского буддизма, готовое полотно с изображением божества обрамляли шелковой или парчовой тканью, при этом вверху - для подвешивания, внизу - для утяжеления прикрепляли деревянные штанги в специально изготовленные отверстия в тканевом «паспарту» [Шараева 2017a: 87]. Благодаря этому полотно висело прямо, а при транспортировке его удобно было складывать в форме свитка. Для сохранности изображения божества на лицевой стороне танка крепили легкую ткань в качестве «занавеса». Практика изготовления танка распространилась вместе с буддизмом.

У калмыков культовая атрибутика буддизма была востребована для оформления хурл (хурул - буддийский храм) и алтарной зоны в жилище. Все предметы культа имели определенное место, выполняли ритуальную, смысловую и декоративную функции.

Несмотря на то, что у калмыков изображения божеств имели общее название «бурхан» (калм. бурхн 'божество'), скульптурные изображения божеств, вылитые из бронзы, меди и серебра и изготовленные из глины и дерева, носили название «шутен» (калм. иүтән), а танка - «живописные изображения бурханов на четырехугольных кусках материи» [Житецкий 1893: 44] «дарцик» (калм. дарцг). Среди них были такие, «которые были принесены с собою еще предками астраханских калмыков, прикочевавших в пределы Волги в XVII веке» [Житецкий 1893: 44].

B XVII - начале XVIII в. предметы религиозного культа большей частью привозились из Тибета и Монголии. Особым почитанием были окружены изображения буддийских божеств, полученные от буддийских иерархов во время паломнических поездок [Шараева 2017a: 86]. 
В конце XVIII в. в связи с прекращением связей с буддийскими центрами увеличилось значение практики изготовления предметов буддийского культа в мастерских калмыцких храмов.

Изготовлением танка занимались зуpaч 'художники' из числа буддийского духовенства. И. А. Житецкий зафиксировал предание, в котором распространение практики изготовления дарцг калмыцкими буддийскими священнослужителями связывают с именем Аюки-хана, который, «чувствуя недостаток в эмчи, зурхачи и бакши, отправился в Тибет к Далай-ламе и с разрешения последнего привез в Астраханскую степь трех лиц: бакши Шарып-ламу, эмчи Ахатен (т. е. Санджи Аракба) и зурхачи Арынкг-Джалтын. И вот с этого времени и начались в степи зурхачи» [Житецкий 1893: 61].

По сведениям И. А. Житецкого, знаменитые зурхачи Малого Шабинеровского хурула Малодербетовского улуса считали себя последователями Арынкг-Джалтына, сохраняющими его практики из поколения в поколение. До 1880-х гг. в этом хуруле жил художник Боро-Манка, у которого учились искусству танкописи «не только зурхачи из Дербетовских хурулов, но и из Торгутовских》 [Житецкий 1893: 61].

По данным А. Д. Руднева, полученным от Бааза Менкеджуева (Бааза-багши), в Малодербетовском улусе был также известен художник Дорця, написавший изображение Тары (Дара-эке), переданное позднее в музей Петербургской академии наук [Руднев 1905: 14].

П. И. Небольсин, побывавший в середине XIX в. в Хошеутовском улусе, также отмечал, что в буддийских храмах улуса («елюнги занимаются живописью) [Небольсин 1852: 186]. Были свои художники в буддийских храмах у калмыков, проживавших на Дону

В XIX и начале XX в. искусству танкописи калмыки обучались, как пишет С. Г. Батырева, в центрах (школах) живописи, среди которых автор называет: «Большой Барунов хурул в Торгоутовском улусе, в Малодербетовском улусе - Дунду хурул и духовная Цаннид - школа (академия) Чёря-хурул, находившаяся на территории современного Целинного района Калмыкии» [Батырева
2005: 85 $]^{2}$. Срок обучения в школах иконописи составлял три года, наряду с живописью ученики изучали скульптуру, каллиграфию и основы архитектуры. Заступником калмыцких буддийских священнослужителей-художников считалось божество Манджушри, «покровитель искусств и всех, стремящихся к знанию» [Бодхисаттва Манджушри].

Началу создания танка традиционно предшествовал обряд очищения, соблюдения постов и молитв, выбор наставника из числа других буддийских священнослужителей. Место работы, материалы и инструменты должны были быть освящены. Во время работы художник должен был воздерживаться от общения с мирянами, соблюдать посты и работать в уединении.

Основой для написания танка у калмыцких художников служили холст и коленкор. Техника подготовки полотна и нанесения рисунка сохраняла его эластичность, необходимую для транспортировки, особенно в условиях кочевого быта: «на проволочную рамку натягивается мокрый холст и рамка укрепляется шнурками в деревянной большого размера. Когда холст высохнет и натянется, его покрывают смесью мыла со столярным клеем. Просохшую поверхность сглаживают рогом. Контур чернят карандашом, а затем наводят тушью, после чего все планы закрываются краской, которую разводят в раковинах жидким раствором клея. Смешения разных тонов избегают, предпочитая чистые краски» (цит по: [Батырева 2005: 86]).

${ }^{2}$ Вызывает вопрос, о каком из торгутских улусов идет речь. Вероятно, речь идет о Большом хуруле Ламринлин Багацохуровского улуса, так как «барун» - одно из подразделений этого улуса. О монастыре Ламринлин известно, что он был в XIX в. разделен на пять хурулов: Большой (Ики) хурул Ламринлин, Большой Манлан хурул, Большой Докшидын-хурул, Малый Данжагин-хурул, Онкоров Малый хурул. В начале XX в. был основан еще один хурул, получивший название «Шебенеров» [Буддийская традиция 2015: 65]. Причем, как отмечали исследователи, в Багацохуровском улусе было всего пять хурулов [Буддийская традиция 2015: 65]. Таким образом, речь идет о Багацохуровском улусе и монастырском центре, который включал все пять хурулов, ранее входивших в основанный еще с прихода калмыков в нижневолжские степи в XVII в. хурул Ламринлин. 
Калмыцкие танкописцы также создавали копии имеющихся изображений божеств, поэтому «восковкой снимают очертания. По ним накалывают трафарет (загбыр)» [Руднев 1905: 8, 14].

На получившемся изображении сначала раскрашивали большие плоскости, затем - детали. Повторно выполнив контур, наносили позолоту, выполняли полировку отдельных участков. На готовых танка в последнюю очередь рисовали глаза, что соответствовало церемонии «открывания глаз).

Краски для изготовления танка использовались минерального и растительного происхождения. Готовые танки были «от $1 / 2$ аршина 3 до сажени ${ }^{4}$ и больше....» [Житецкий 1893: 44].

Во время определенных религиозных служб танка выносили за пределы буддийского храма, после троекратного совершения обхода с внешней стороны по кругу в направлении движения солнца и общего поклонения членами прихода их возвращали на место. Если проводились большие молебны, то танка, особенно большого размера, подвешивали на специальных столбах на территории хурула до окончания службы.

При создании своих произведений калмыцкие художники пользовались тибетским пособием по иконографии «Тик-зачангрль» или «Тик-зад» [Руднев 1905: 8, 15], а также монгольским «Дегеду амугуланг санвар) [Львовский 1898: 25].

Согласно буддийскому канону каждое божество пантеона изображалось в определенных пропорциях, с набором обязательных признаков: поза, тип телосложения, эманация определенного цвета, атрибут и т. д. Если на танка изображалось одно божество, то непременно справа рисовали солнце, слева - луну. Изображали божество, окруженное целым рядом изображений других божеств или символов. Так, например, вокруг центральной фигуры Будды Шакьямуни часто изображали картины из его жизни от рождения до смерти, а изображение божества Амитабха выполнялось в окружении 8 субурганов. На танка с большим количеством изображенных божеств главное выделялось на фоне второстепен-

\footnotetext{
${ }^{3}$ Аршин - старинная мера длины, равная $71 \mathrm{~cm}$.

${ }^{4}$ Сажень - старинная мера длины, равная $2,13 \mathbf{M}$
}

ных персонажей: «в центре представлен в сравнительно большем размере бурхан Майдри, вверху справа - Дарька, слева Чакшиб́, с боку справа - Лама, Аюша, Одче-бурхан, слева - Юм, Манза Шири, Абидва; внизу - Далай лама, Зонкуа и Баньчен-Эрдни» [Житецкий 1893: 45].

Сформировавшийся 《свой» состав буддийского пантеона божеств и практика отхождения от строгих канонических требований в их изображении, сложившаяся буддийская храмовая и мирская практика, сочетавшая традиции буддизма и культурные особенности калмыков, обусловили формирование этнического варианта искусства буддизма у калмыков. По мнению С. Г. Батыревой, внешними характерными признаками калмыцких танка были яркая, нередко контрастная без полутонов цветовая гамма, гибкий контурный рисунок и строгая симметричная композиция, потому что за длительный период освоения и накопления профессиональных знаний произошло преломление классического буддийского канона в соответствии с мировоззрением и национальной эстетикой народа, его традициями [Батырева 2005: 117]

И. А. Житецкий считал, что «техника калмыцкой живописи довольно примитивна и характеризуется отсутствием перспективы и мертвенным однообразием всех изображений бурханов; только по цвету лица и аксессуарам рисунков можно отличить изображение одного бурхана от другого: все они (исключение составляют разве изображения злых духов) снабжены одною типичною физиономией: широким, почти круглым лицом, узкими скошенными глазами, коротким носом и несоразмерно длинными ушами〉 [Житецкий 1893: 64]

Д. В. Иванов, детально исследовавший калмыцкие танка в коллекциях Музея антропологии и этнографии им. Петра Великого (Кунсткамеры) Российской академии наук, пришел к выводу, что они имеют отклонения в канонах, принятых в буддизме Тибета, Бурятии и Монголии, например, несоответствие цветов изображения как самого божества, так и его атрибутов [Иванов 2008: 51-52].

Исследователь выделяет ряд характерных особенностей калмыцкого стиля написания танка. Во-первых, ландшафтный фон изображается украшенным полевыми цветами и кустиками с тремя или четырьмя 
веточками, со схематичным изображением воды и гор, часто смещенных в самый низ полотна. В цветовом обозначении ландшафта преобладает зеленый цвет, но встречаются изображения «выжженной летней степи». Во-вторых, особенностью, выделяющей божеств, изображенных на калмыцких танка, являются широкие «приплюснутые» носы и наивные «детские) черты лица. В обрамлении фигуры божества тюльпаны часто бывают нарисованными над цветком лотоса. Как отмечает Д. В. Иванов, «калмыки к началу XX в. сумели создать собственный легко узнаваемый стиль буддийской живописи, отличающийся некоторым „примитивизмомее, но подкупающий искренностью и оригинальностью» [Иванов 2009: 31 ].

При анализе калмыцких танка, хранящихся в фондах Национального музея Республики Калмыкия им. Н. Н. Пальмова, И. И. Мучаева также обратила внимание на нарушение канона при изображении буддийских божеств и их атрибутов [Мучаева 2003: 33].

Вышивка в изготовления изображений божеств

У калмыков существовала также практика изготовления изображений божеств в технике вышивки. И. А. Житецкий, достаточно подробно исследовавший жизнь калмыцкого духовенства и хурулов, отмечал наличие вышитых шелком, золотыми и серебряными нитями изображений буддийских божеств практически со времени прихода калмыков в степи Северного Прикаспия. Вышитая танка в Большом хуруле Малодербетовского улуса, например, была датирована им примерно 1769 г. По его сведениям, работа по созданию этой вышитой танки выполнялась в течение трех лет [Житецкий 1893: 45].

Изготовление танка в технике вышивки у калмыков активно практиковалось, несмотря на трудоемкость и длительность процесca, на что указывают данные И. А. Житецкого о наличии «старых и новых дарциках» в Большом хуруле Яндыковского улуса и Большом Баруно-Керетовом хуруле Яндыковского улуса, при этом новые были изготовлены в 1870-х гг. [Житецкий 1893: 45].

Вышивка изображений божеств буддийского пантеона производилась под руководством танкописца буддийского храма. Придерживаясь традиционных правил и ка- нонов по созданию танка, художник наносил контур рисунка на ткань, по которому выполнялась работа мастериц. Танка вышивали девочки и молодые девушки, замужние женщины и вдовы. Девочек и девушек для выполнения такой работы привлекали и из числа служанок знатных калмычек, «этот штат девочек в свободное от услуг госпоже время сидит за рукоделием, и их трудом выделывают тесьмы, позументы и прочее» [Житецкий 1892: 74].

Для них и вдов устанавливали специально жилище на территории храма, в которых они проживали до окончания работы по созданию танка. Замужние женщины, участвовавшие в процессе вышивки божеств, брали работу на дом. Их искусство в технике гладьевого шитья было настолько целостным и профессиональным, что «не сразу разберешь, что бурхан вышит, а не нарисован блестящими красками, так хорошо подобраны цвета и так тонка работа во всех деталях〉 [Житецкий 1893: 45]. В большей степени этот эффект достигался за счет применения мастерицами традиционной техники вышивки в полутонах

Достаточное количество привлеченных мастериц позволяло создавать вышитые танка больших размеров. И. А. Житецкий упоминает в своих работах, в основном, о вышитых изображениях божества Майтреи, которое было особо почитаемо у калмыков, при этом подчеркивая, что «всегда в громадных размерах» [Житецкий 1892: 83].

Вместе с тем до наших дней сохранилась, напомним, уникальная танка Зеленой Тары, хранящаяся в настоящее время в фондах Ставропольского государственного объединенного краеведческого музея им. Г. Праве (рис. 1, 2). Калмыки почитали две формы Тары: как воплощение будды деяния она выступает в виде Зеленой Тары, обладающей телом изумрудно-зеленого цвета, как воплощение будды долгой жизни в виде Белой Тары, обладающей телом цвета белого лотоса. Вместе с тем наибольшей популярностью пользовалась Зеленая Тара, на что указывает большое количество изображений этого божества в различных коллекциях музейных фондов и в различных домашних алтарях у калмыков.

Сохранившаяся вышитая танка Зеленой Тары была частью триптиха, изготовленного для нового буддийского храма в ставке 


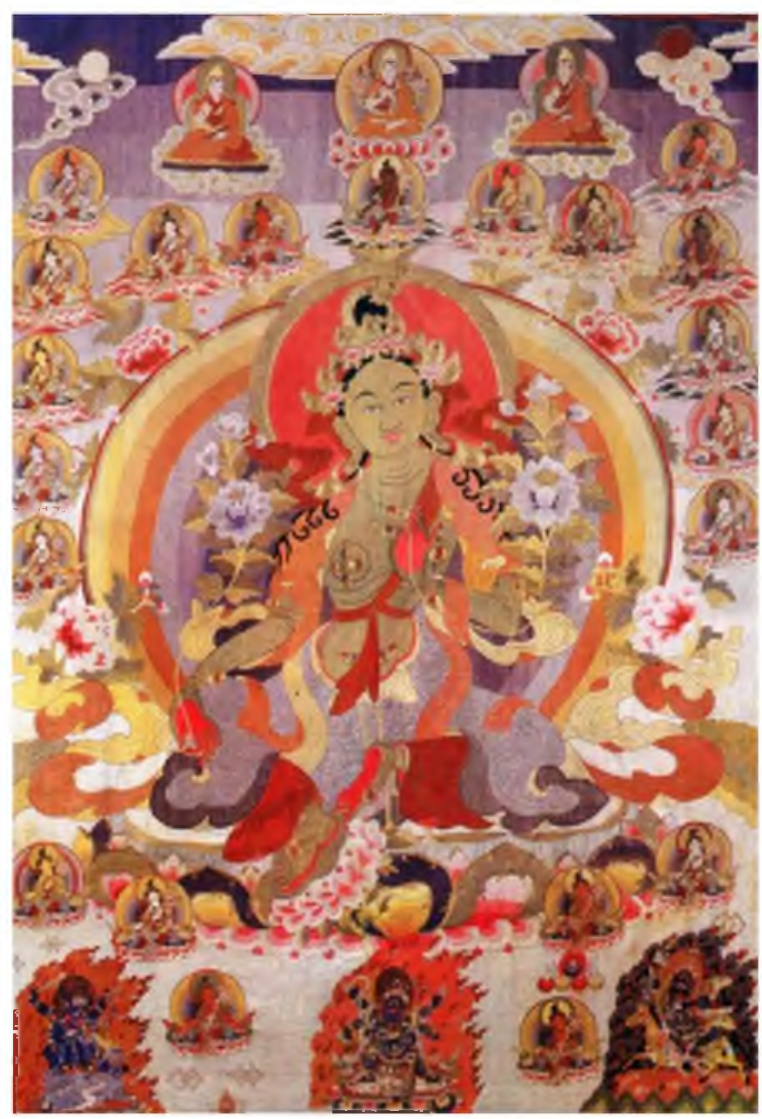

Рис. 1. Зеленая Тара [Зеленая Тара 1992] [Fig. 1. Green Tara]

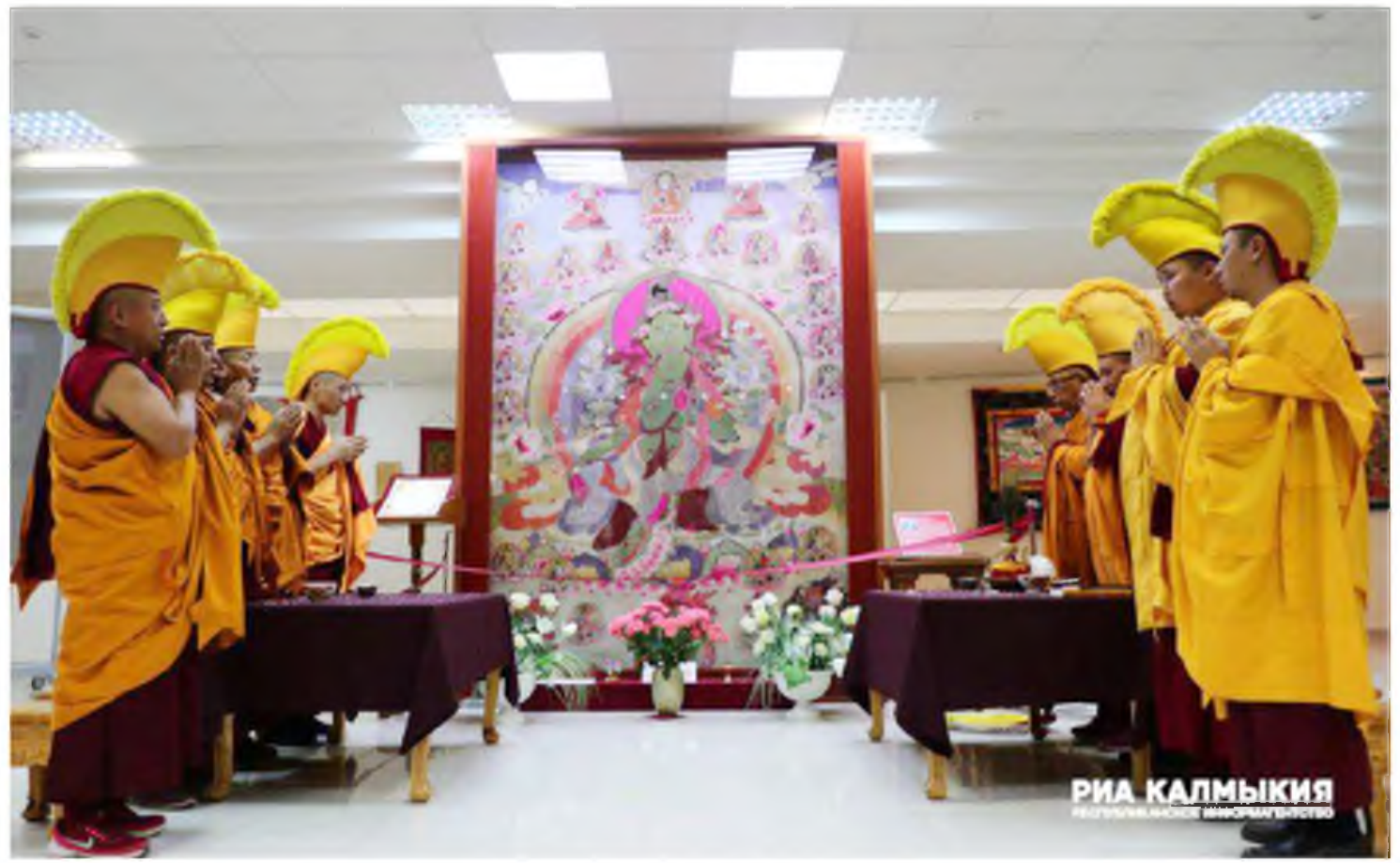

Puc. 2. Открытие выставки Зеленой Тары в г. Элисте. 2020 г.

[В Калмыкии открылась 2019]

[Fig. 2. Opening of the Green Tara exhibition. Elista, 2020] 


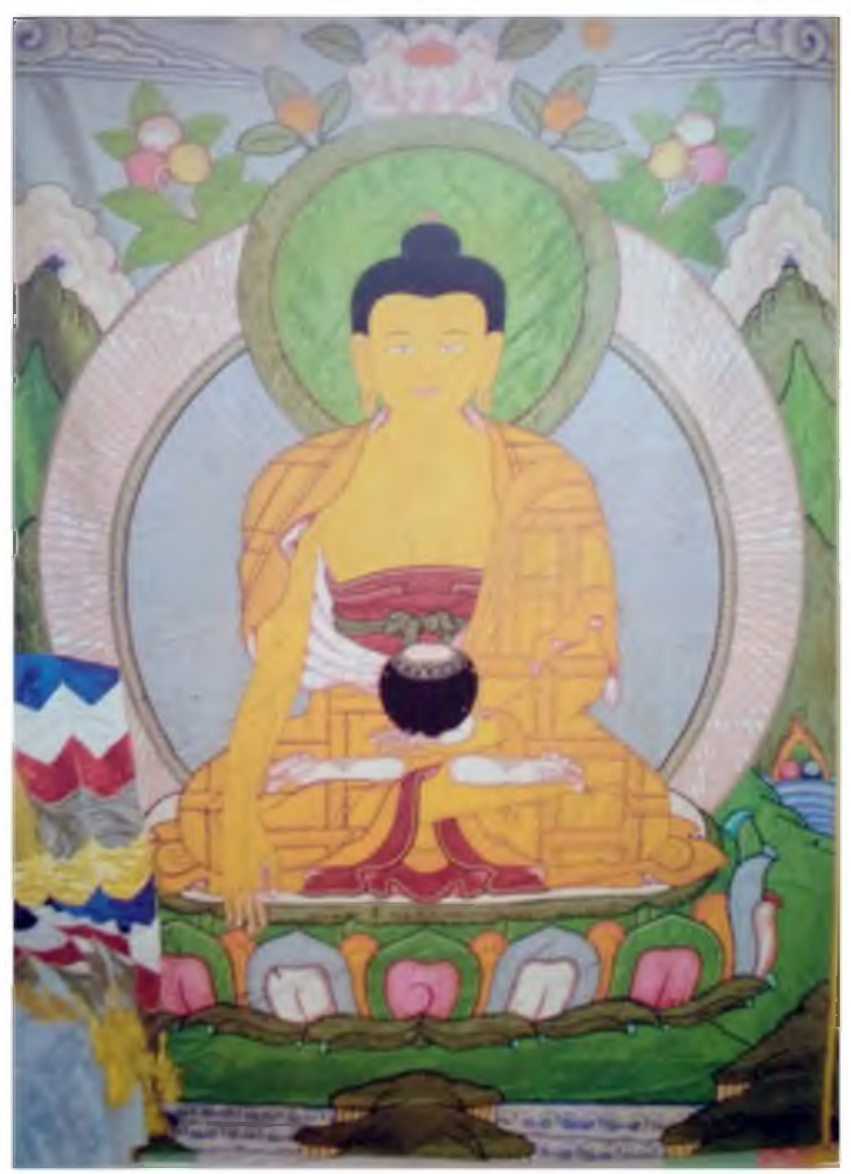

Puс. 3. Будда Шакьямуни. Триптих, центральная часть. 1912-1914 гг. Частная коллекция

[Fig. 3. Shakyamuni Buddha. Triptych, central part. 1912-1914. Private collection]

Бага-Тугтунского аймака Большедербетовского улуса, построенного честь 300-летия Дома Романовых в течение двух лет. На открытии буддийского храма в 1913 г. новую танка размером 2 на 3 метра, вышитую на шелке шерстяными, шелковыми, золотыми и серебряными нитями в технике гладьевого шитья, поместили в алтарной части храма рядом с двумя другими изображениями Зеленой Тары, изготовленными ранее в технике вышивки и аппликации, составив тем самым законченную трехчастную композицию. В буддийской танка, вышитой калмыцкими мастерицами в начале $\mathrm{XX}$ в. облик Зеленой Тары полностью соответствует канонам. Кроме центральной фигуры Тары, на танка вышиты фигуры двадцати одной Тары, защитников Учения, а также (в верхней ее части) Будды Шакьямуни с учениками Кхедрубом-ринпоче и Гъялцабом-ринпоче. В нижнем поле танка вышиты изображения защитных божеств, традиционных для школы Гелуг, каждое в окружении языков пламени: Каларупа, танцуюший на буйволе; шестирукий Махакала, попирающий ногами белого Ганешу; Окон Тенгри (Лхамо) на муле [Нурова 2007: 156; Зеленая Тара 1992].

У этой танка печальная история. После закрытия буддийского храма в 1930-х гг. maнка Зеленой Тары пропала. В 1946 г. ее случайно увидела на одном из рынков Ставрополя, где ее продавали как гобелен, музейный работник Татьяна Максимовна Минаева. Понимая ценность танка и осознавая, какая у нее может быть участь, женщина выменяла ее на две буханки хлеба, что в голодные послевоенные годы было решительным и благородным поступком.

Еще одной реликвией и образцом традиции изготовления танка в Калмыкии является сохранившаяся часть триптиха «Будда Шакьямуни» (рис. 3), выполненная в начале XX в. в хуруле станицы Эркетеневской Сальского округа. Рисунок на шелковой ткани, специально привезенной из Тибета 


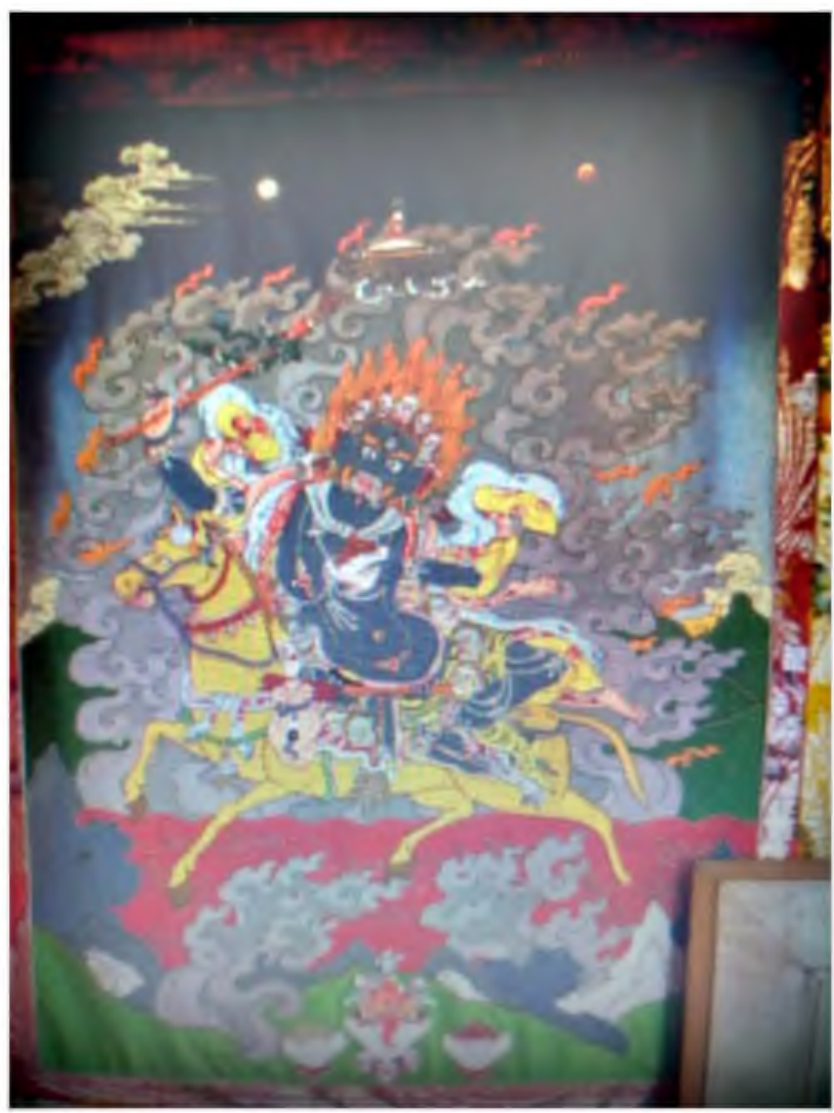

Рис. 4. Панчен Лхамо (калм. Окон Тенгри), п. Чилгир, Яшкульский район Республики Калмыкия. Фото автора. 2017 г.

[Fig. 4. Palden Lhamo (Kalm. Okon Tengri). Chilgir village, Yashkulsky District, Republic of Kalmykia Photo by author]

для изготовления танка, составил зурач художник этого храма Кирип Бадаков. Триптих в технике аппликации зегт нәәмл (букв. 'окаймленная клееная работа') и вышивки был изготовлен в течение двух лет. Вырезанные из шелка и парчи формы и фигуры крепились по краям шнуром, свитым из шелковых нитей, а также золотыми и серебряными позументами, которые мастерицы изготавливали в процессе работы. В изготовлении изображения Будды Шакьямуни сочетались приемы: хатхмр 'шитье нитками', күсм 'нашивки из позумента', чимкәр 'нашивки из шелка, парчи (сукна, хлопчатобумажных тканей, войлока и меха)', утщн 'окаймляющая края полотна обшивка из шнурка', зег 'наложение по контуру рисунка ниток, шнурка и тесьмы, скрепленных второй ниткой’. Как отмечает С. Г. Батырева, танка была лаконичной по композиции, четкой по рисунку и сдержанной в цветовом решении [Батырева 1991: 32].
В 2003 г. в молельный дом в п. Чилгир Яшкульского района была передана в дар танка с изображением божества Палден Лхамо (калм. Окон Тенгри) (рис. 4.) Д. Кичиковым, уроженцем поселка, проживавшим в США. Эта танка хранилась в семье и была выполнена в технике аппликации и вышивке, сходной той, которой был выполнен триптих «Будда Шакьямуни».

\section{Современные буддийские практики и} женское рукоделие

По мнению исследователей, «в современном буддизме в Калмыкии выделяются несколько сфер: буддийские храмы, религиозные центры мирян, общины пожилых калмыков, практикующих ритуалы поста, с сохранением наборов молитв и обрядов, бытовавших еще в начале XX в. Кроме того, существует практика так называемых ,знающих более последовательными приверженцами 
„чистого бе буддизма в качестве „шаманистов". Перспективы развития буддизма в Республике Калмыкия ныне связываются с развитием всех уровней его бытования» [История буддизма 2011: 104]. В Калмыкии также принято различать храмовую и мирскую буддийские практики.

Среди современных калмыков распространено мнение, что покровительство буддийских божеств в повседневной жизни можно достичь «принятием [покровительства] божества), изображения которых составляют алтарь, и исполнением соответствующих ритуалов - бурх авх (букв. бурхан, божество [КРС 1977: 121], брать / взять / получать / принимать / доставать, добывать [КРС 1977: 23]), бурхан залх (букв. бурхан, божество [КРС 1977: 121] управлять / направлять / заведовать / распоряжаться [КРС 1977: 239]).

Основой такого распространенного мнения послужили, на наш взгляд, усиление позиций буддизма в Калмыкии, развитие домашней формы религиозности и получение более глубоких знаний о буддийской практике мирянами. Если еще в начале 2000-х гг. многие молодые калмыки задавались вопросом о символике и функциях тех или иных божеств, о религиозной атрибутике, старались постичь основы буддизма во время лекций буддийских священнослужителей местных храмов и учителей, приезжавших из буддийских центров Индии, Монголии и Бурятии, то в настоящее время буддизм воспринимается на более глубоком уровне. Этому также послужила разъяснительная работа представителей буддийской церкви, выпуск большого количества буддийской литературы, в том числе сборников молитв на калмыцком языке, разъяснение символики и значения религиозных обрядов и празднеств перед их проведением и т. д.

На этом же представлении базируется повсеместная практика создания личных и семейных алтарей молодыми калмыками. Например, многие калмыки-студенты, обучающиеся за пределами республики, создают в местах проживания алтари с поддержкой родителей и близких, которые участвуют в оформлении: подбирают необходимые предметы религиозного культа, определяют божество-покровителя по году рождения, изображение которого затем освящают для «пробуждения) посредством чтения мо- литв буддийскими священнослужителями, обучают совершать подношения на алтаре, в том числе деељс 'первинками пищи', правильно зажигать лампаду в дни поста и праздники, и т. д.

Если молодые люди действуют самостоятельно, то последовательность действий по созданию алтаря и соблюдение буддийских практик просто уточняют у родных, обращаются к буддийским священнослужителям или основываются на своих знаниях, участвуя в молебнах и совершении подношения у алтаря в кругу семьи.

Сходные действия при создании домашнего алтаря совершают и семейные пары молодых калмыков. Изображения божеств, приобретаемые ими для создания алтаря, часто бывают копией в виде фотографий старинных калмыцких танка, хранящихся на алтаре родителей. Если обращаются к буддийскому священнослужителю для определения личного божества-покровителя и общего для семьи, то изображения божеств и культовую атрибутику для оформления алтарной зоны приобретают в магазинах, специализирующихся на продаже предметов религиозного культа в Элисте и других городах, или привозят из мест паломничества в Индии, Монголии, Бурятии. Создание семейного алтаря воспринимается семейной парой как один из символов их союза, показатель приверженности буддизму и этнический маркер.

С 2000-х гг. в Республике Калмыкия увеличился туристический поток, часть которого является паломниками. Открытие в 2005 г. одного из крупнейших буддийских храмов в Европе - «Золотой обители Будды Шакьямуни) ('Бурхн-Багшин Алтн Сүм') - способствовало утверждению Калмыкии как одного из значимых буддийских центров не только в России, но и за ее пределами. Паломники и туристы, приезжающие в республику, были заинтересованы в приобретении сувенирной продукции местного производства и атрибутов буддийского культа. Надо отметить, что в этот период и сами калмыки нуждались в различных предметах религиозного культа, специальной литературе и сувенирной продукции, которая отражала бы их национальный колорит и религиозные воззрения. Первоначально рынок востребованной продукции был заполнен товарами из Китая и Монго- 
лии, символика которых на волне процессов этнокультурного возрождения народов на всем постсоветском пространстве воспринималась как «своя», «родная символика», обусловленная общностью истории и этногенетическими связями в прошлом.

По мере роста проявлений этнической идентичности, накопления знаний о традиционной культуре и практиках буддизма, появления местных ремесленных мастерских и развития этнического предпринимательства «сегодня в Калмыкии появилось большое количество сувениров, которые можно отнести к чисто региональной продукции, произведенной в республике. Желание выразить этнические особенности привело к тому, что производители (иногда они же и продавцы) стали выпускать продукцию с ярко выраженным калмыцким этническим компонентом, востребованную продавцами, следящими за покупательским спросом, и покупателями, желающими приобрести изделия этнических предпринимателей как для повседневного пользования, так и в качестве сувенирной продукции» [Шараева 2017б: 79]. К их числу относятся и предметы буддийского культа, например: украшенные калмыцкой символикой статуэтки Белого старца и божеств буддийского пантеона, украшения и талисманы, металлические и деревянные чаши для подношений и т. Д.

Возвращаясь к изображению буддийских божеств, распространенных в Калмыкии, необходимо обозначить две тенденции, сложившиеся в настоящее время.

Во-первых, во многих калмыцких семьях хранятся изображения божеств в виде свитка танка или холста с изображениями, оформленного в деревянную раму под стеклом, которые являются семейными реликвиями, бережно хранимыми не одно десятилетие. По желанию другие члены семьи могут заказать копию или подобрать максимально сходное изображение божества, воспринимая исходное божество как семейное. Такое изображение божества впоследствии располагают на домашнем алтаре рядом с изображением божеств, определенных соответственного году рождения каждому члену семьи. Нередко древние изображения божеств, хранимые в калмыцких семьях, воспринимаются общеродовыми: либо потому что когда-то оно находи- лось в прошлом в стенах родового храма, либо потому, что нынешний ее хранитель является потомком главы рода, перенявшим его функции.

Как известно, антирелигиозная пропаганда конца 1920-х гг. привела к тому, что «к началу 1940-х гг. ХХ в. калмыцкое духовенство было почти полностью уничтожено, так же как и буддийская церковь в Калмыкии, уничтожена не только идейно и организационно, но нередко и физически» [Басхаев 2007: 16].

На долгие десятилетия, начиная с незаконной депортации в 1943 г. в восточные районы страны и до конца 1980-х гг., калмыки были лишены возможности открыто проявлять свою приверженность буддизму. Вместе с тем, по данным исследователей, буддизм продолжал сохраняться и практиковаться в нескольких формах: «тайной общине) бывших священнослужителей, которые съезжались под видом «гостей» для проведения совместного молебна; общине верующих ((мацгта) - те, кто придерживался постов, устраивали 8,15 и 30 числа каждого лунного месяца общий молебен и недельные каждодневные службы после наступления весеннего праздника Цаган Сар и зимнего праздника Зул, а также в форме домашней религиозности [Бакаева 2009: 15].

Еще в 1930-е гг. во время репрессий и разрушения буддийских храмов многие калмыки тайно забирали домой предметы религиозного культа и скрыто проводили соответствующие обряды и молебны в кругу родных и представителей других родовых групп, являвшихся приходом данного хурула, или закапывали эти предметы. В конце 1990-х гг., основываясь на рассказах представителей старшего поколения, некоторые калмыки стали извлекать из земли в местах нахождения в прошлом калмыцких храмов культовую атрибутику, в том числе изображения божеств, бережно упакованных и зарытых для сохранения и избегания осквернения.

Если религиозные предметы культа в период репрессий в 1930-е гг. оставались в семье, то во время депортации калмыцкого народа в декабре 1943 г., отправляясь в ссылку, когда люди брали с собой самое ценное, многие везли с собой предметы религиозного культа (четки, статуэтки божеств, танки, жертвенные чаши и т. д.). 
Существует немало устных историй, в которых рассказывается, что под одеждой на теле людей, умерших во время следования к месту поселения, находились танка так они пытались сохранить святыни; в местах временного поселения в период ссылки, даже отравляясь на рабочие места, многие носили с собой предметы религиозного культа, опасаясь обысков в местах проживания; глубокой ночью зажигали привезенные с собой лампады для прочтения хотя бы одной молитвы перед ликом божества и т. д.

Несмотря на то, что большое количество предметов буддийского культа было изъято у калмыков и безвозвратно утеряно, многие калмыки все же сумели сохранить семейные реликвии и привезти их обратно в Калмыкию.

О значении буддизма как религии в жизни калмыков и непрерывности традиции можно судить не только по сохраненным древним изображениям божеств, но и по бережно хранимым на домашних алтарях древним тибетским и ойратским рукописям и ксилографам, являющимся памятниками буддийской литературы и неотъемлемой частью духовной культуры калмыков. Выявленный в калмыцких семьях Д. Н. Музраевой в 2000-х гг. репертуар буддийских письменных памятников, имевших хождение среди калмыцких буддийских священнослужителей и верующих мирян в XIX$\mathrm{XX}$ вв., также указывает на «значимость буддийской составляющей в системе и среде современной калмыцкой культуры〉 [Музраева 2012: 8]. Такие реликвии буддийского культа передаются у калмыков по наследству с учетом старшинства по мужской линии (от отца - старшему сыну).

Во-вторых, по мере накопления знаний о калмыцкой форме буддизма калмыки-миряне вместо востребованной в первое время любой продукции с буддийской тематикой и символикой, привозимой больше всего из Китая и Монголии, стали отдавать предпочтение тем атрибутам и изображениям божеств, которые, по мнению самих же калмыков, имеют сходные специфические черты с калмыцкой формой буддизма XIX начала XX в. Например, отличительными чертами изображений «калмыцких" божеств, по мнению современных калмыков, являются: отсутствие пышного и яркого оформления пространства вокруг божеств, лаконичность красок и отсутствие полутонов, разграничение фона с выделением преимущественно голубым или синим цветом неб̆а, зеленым - жизненного пространства, небольшое количество растительности, где преобладают полураскрытые тюльпаны различного окраса или цветы, похожие на них, обязательное обозначение луны и солнца, к которым направлены вытянутые края слоисто-кучевых облаков, схожесть лика божеств с антропологическим типом калмыков, характерным для представителей центральноазиатского типа монголоидной расы (выделяют форму лица, носа, глаз, ушей: плоское лицо, высокое переносье и приплюснутый нос с широкими ноздрями, узкие глаза, большие и вытянутые уши). По мнению калмыков-мирян, изображения божеств буддийского пантеона, несмотря на выполнение по определенным традиционным канонам, все же отражают национальную специфику региона, в котором распространен буддизм.

Одной из сфер жизни современного калмыцкого общества, в которой остро обсуждаются вопросы о калмыцкой специфике в изображении божеств буддийского пантеона, является женское рукоделие. За последнее десятилетие вышивка изображений божеств как вид рукоделия стала актуальной в контексте развития буддизма, мирской формы буддийских практик, женского досуга, этнического предпринимательства.

В начале 2000-х гг. наборы для вышивания крестиком с изображением буддийских божеств, произведенные в Китае и Монголии, начали завозить одновременно с предметами религиозного культа и сувенирной продукцией. Они были хорошего качества с достаточным количеством нитей, иглой, канвой и схемой, но с подробными инструкциями на китайском языке. Количество их всегда было ограниченным, стоили очень дорого. Возможность изготовить изображение божества самостоятельно в условиях дефицита атрибутов буддийского культа, схожесть внешнего вида готового изделия с танка в действующих буддийских храмах Калмыкии, последующее размещение оформленной вышивки изображения буддийского божества в алтарной части дома - одни из основных причин появления такой формы рукоделия. Подобной вы- 


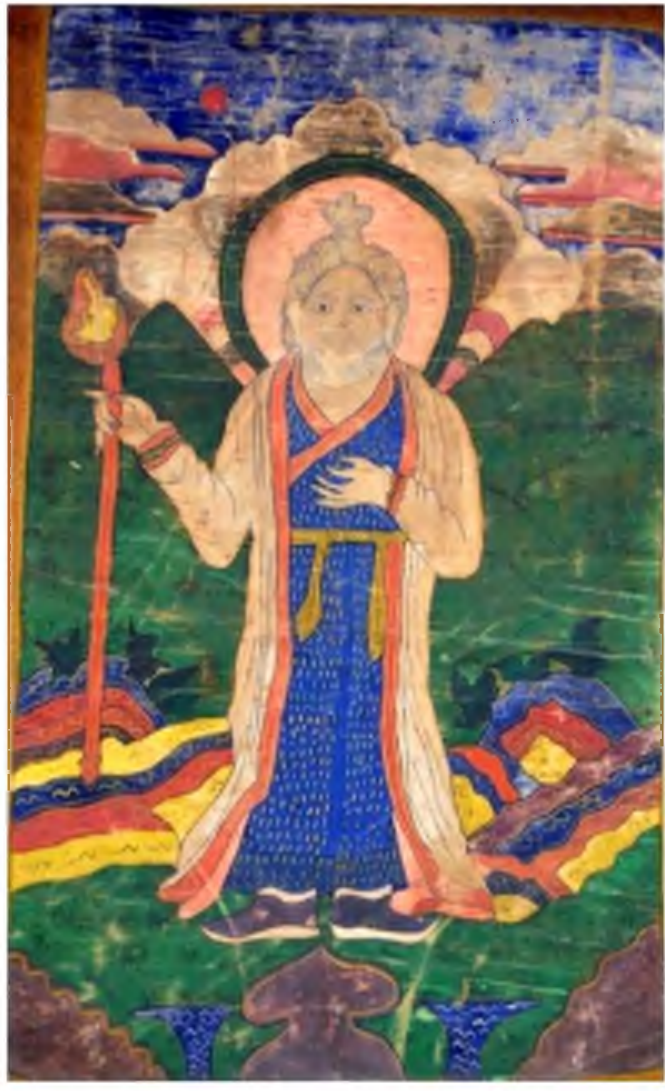

Puc. 5. Белый старец. 1801-1925 гг. Музей традиционной калмыцкой ку льтуры им. Зая-пандиты КалмНЦ РАН [Цаган Аав 1801-1925]

[Fig. 5. White Old Man. 1801-1925. Zaya Pandita Museum of Kalmyk Traditional Culture, Kalmyk Scientific Center of the RAS]

шивкой в тот период занимались женщины, чье взросление и молодость прошли в период распространения советской идеологии, и с нюансами религиозных канонов они не были знакомы, поэтому только по завершении работы и оформлении вышивки в виде свитка mанка они отправлялись с подношениями в буддийских храм для ее освящения. Информацию о том, что изображение божества будет 〈живым» только после чтения специальной молитвы буддийским священнослужителем, мастерицы получали от представителей старшего поколения калмыков.

Следующий этап развития данного вида рукоделия связан с очередным этапом развития буддизма в республике и углублением знаний об основах буддизма калмыками, с активным строительством культовых объектов. В этот же период стало распростра-

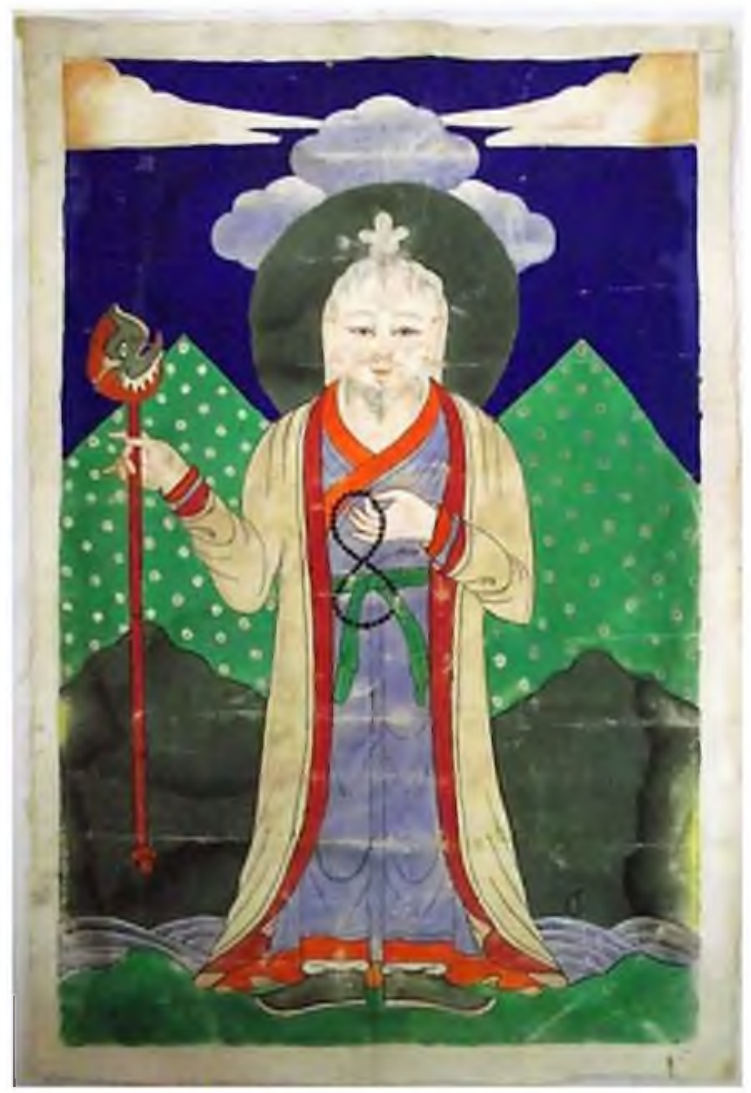

Puc. 6. Белый Старец. Новочеркасский музей истории донского казачества [Белый старец 2020]

[Fig. 6. White Old Man. Novocherkassk Museum of Don Cossack History]

няться мнение, что особого расположения божества можно добиться, если самостоятельно изготовить его изображение и совершить им подношение храму. Поэтому свои вышитые работы мастерицы не только оставляли для домашнего алтаря, но и стали передавать в буддийские храмы. Но, по объяснениям буддийских священнослужителей, данным мастерицам, изображение божества, приносимого в дар храму, не могло быть установлено на алтаре или использоваться во время служб, так как выполнено без соблюдения постов и без ритуалов последовательного процесса «пробуждения» божеств при создании, а также в готовом изделии прослеживались некоторые нарушения канона изображения божеств. Выход был найден следующим образом: вышитые mанка после совершенных неоднократных молитв и ритуалов над ними закладывали 


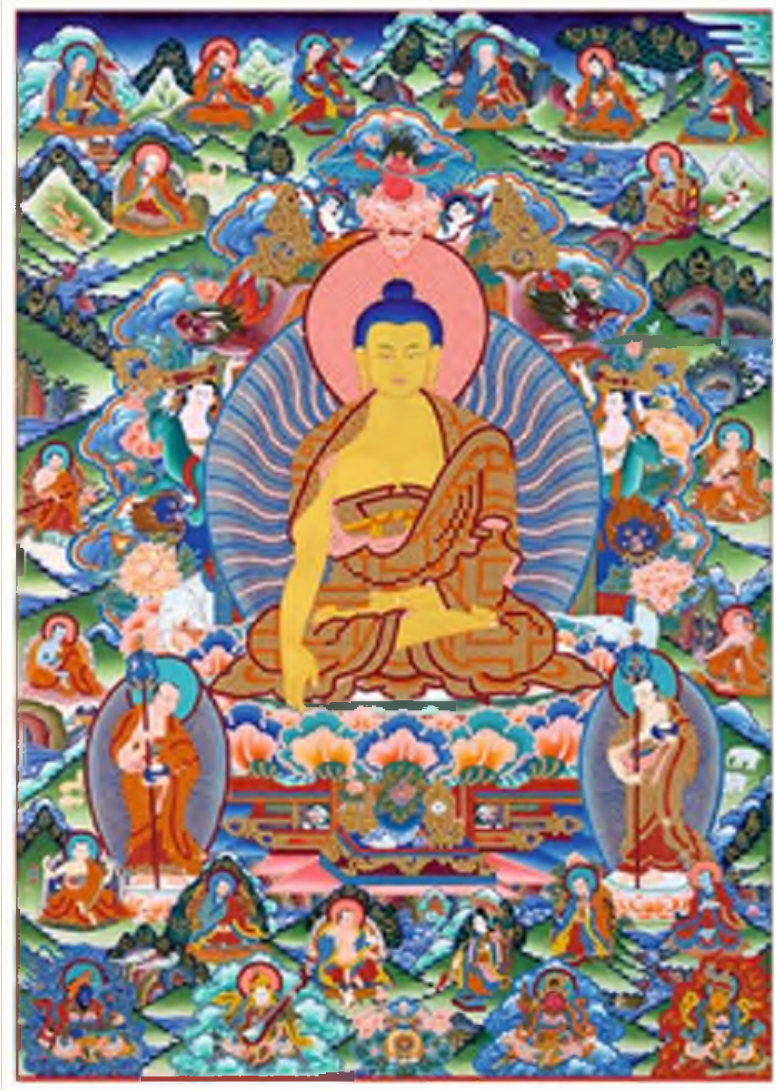

Puc. 7. Будда Шакьямуни. Производитель - «Русская сказка».

Частичная зашивка, ткань - атлас

[Fig. 7. Shakyamuni Buddha. Manufactured by Russkaya Skazka]

при строительстве ступы с мотивацией совершения подношения. Данная практика сохраняется в настоящее время, чему немало способствует активное строительство буддийских ступ в республике, число которых уже достигло 40 [История буддизма 2011: 95].

На встречах с Его Святейшеством Далай-ламой XIV в г. Риге калмыцкие мастерицы преподносили ему свои работы в качестве подношения. Эта практика стала распространяться и в Калмыкии. Так, во время посещения республики досточтимому Арджа Лобсан Туптен Ринпоче калмыцкие мастерицы преподнесли подношения в виде вышитых изображений божеств буддийского пантеона, выполненных в разных техниках.

Широкое распространение данный вид рукоделия у калмыцких мастериц все же получил в последнее десятилетие. Разнообразились техники и материалы. Наряду с изготовлением вышитых изображений бо- жеств буддийского пантеона для домашнего алтаря их стали изготавливать для продаж туристам и паломникам, желающим привезти домой танка из Калмыкии как отражающую региональную специфику буддизма в России - спрос породил предложение. Но необходимо отметить одну особенность с продажи каждой танка мастерицы обязательно выделяют некоторую сумму в качестве подношения в буддийский храм.

Многие магазины, специализирующиеся на товарах для рукоделия, например «Мастерица», «Лу», «МеСаДе», «Мария»,, «Радуга», стали расширять ассортимент завозимых товаров. В продаже появились наборы для вышивки крестом и бисером в технике частичной и полной зашивки на напечатанной и чистой основе, а также в гладьевой технике. Основными поставщиками такого рода товаров, наряду с такими полюбившимися китайскими фирмами, как, например, «NKF» и «JOY SUNDAY», с соотношением «цена - качество», стали фир- 


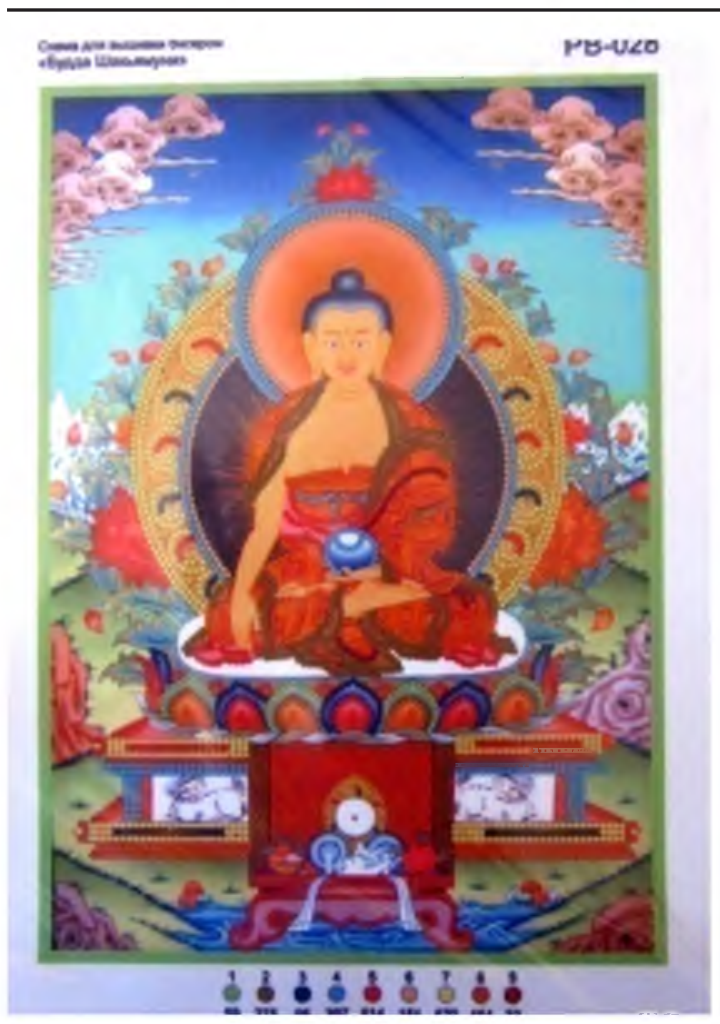

Puс. 8. Будда Шакьямуни. Производитель «Русская сказка». Частичная зашивка, ткань - габардин. Магазин «Радуга» в г. Элисте. Фото автора, 2020 г.

[Fig. 8. Shakyamuni Buddha. Manufactured by Russkaya Skazka. Partial embroidery kit, fabric - gabardine. Raduga retail store, Elista. Photo by author. 2020]

мы и интернет-магазины: «Русская сказка) (г. Псков), «Художественные мастерские» (г. Ставрополь), «Могулан» (г. Улан-Удэ), «Страна рукоделия) (г. Харьков) и др.

На первоначальном этапе фирмы-поставщики предлагали тот товар, который был в наличии, сейчас изменили и расширили ассортимент товаров, ориентируясь на запрос покупателей. Так, владельцы местных товаров для рукоделия закупали в основном изображения Будды Шакьямуни, Аволакитешвары, Зеленой и Белой Tap, Майтреи. В настоящее время в составе заказов указаны изображения более 15 божеств буддийского пантеона. Необходимо отметить особенность: по изображениям двух божеств - Цзонкапы и Белого Старца - наборов или основ для вышивки не производят. Вместе с тем, учитывая постоянный спрос мастериц, владелица магазина «Радуга» М. В. Букаева разра-

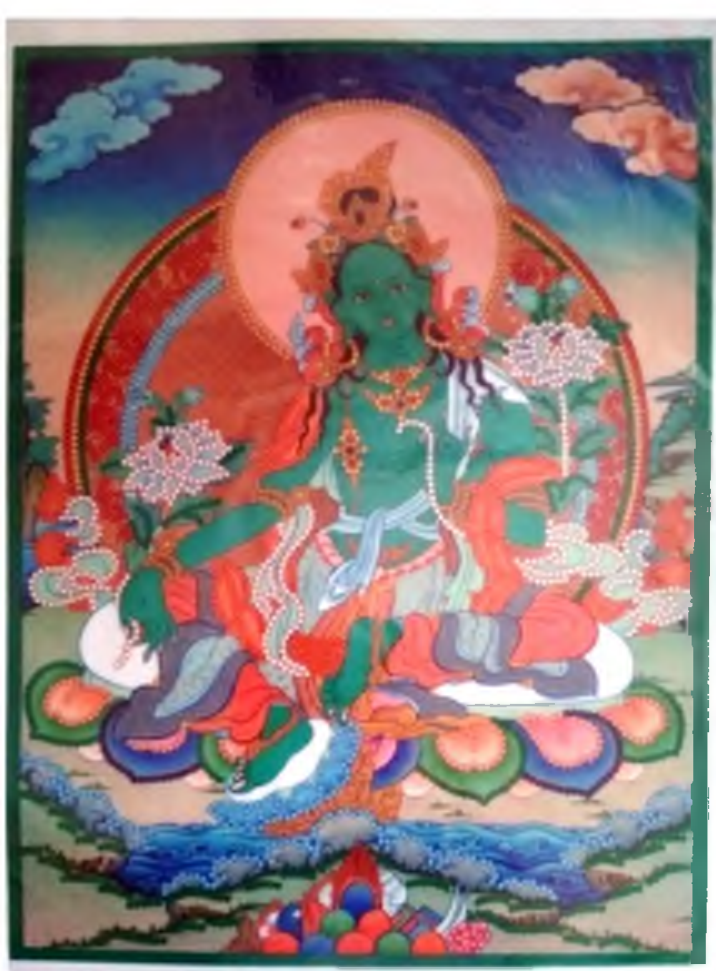

Рис 9. Зеленая Тара. Производитель «Русская сказка». Частичная зашивка, ткань - габардин. Магазин «Радуга» в г. Элисте. Фото автора, 2020 г.

[Fig. 9. Green Tara. Manufactured by Russkaya Skazka. Partial embroidery kit, fabric - gabardine. Raduga retail store, Elista. Photo by author. 2020]

ботала в 2020 г. различные варианты схем буддийских божеств для вышивания бисером, выпускаемых под торговой маркой с одноименным названием. Схемы, определяемые мастерицами как «калмыцкие», то есть имеющие наибольшее сходство со старинными калмыцкими танками, пользуются наибольшим спросом. Например, вместо изображения Белого Старца в виде отшельника, сидяшего у грота под персиковым деревом в окружении брачных пар оленей и журавлей, предпочтение отдается изображению стоящего Белого Старца с седыми волосами в белом халате, в правой руке держащего посох с навершием в виде головы дракона, в левой - четки, пейзажным фоном которого служит пространство с цветовым разграничением небесного и земного пространств (рис. 5, 6).

Производители схем в технике вышивки бисером используют атлас, габардин 


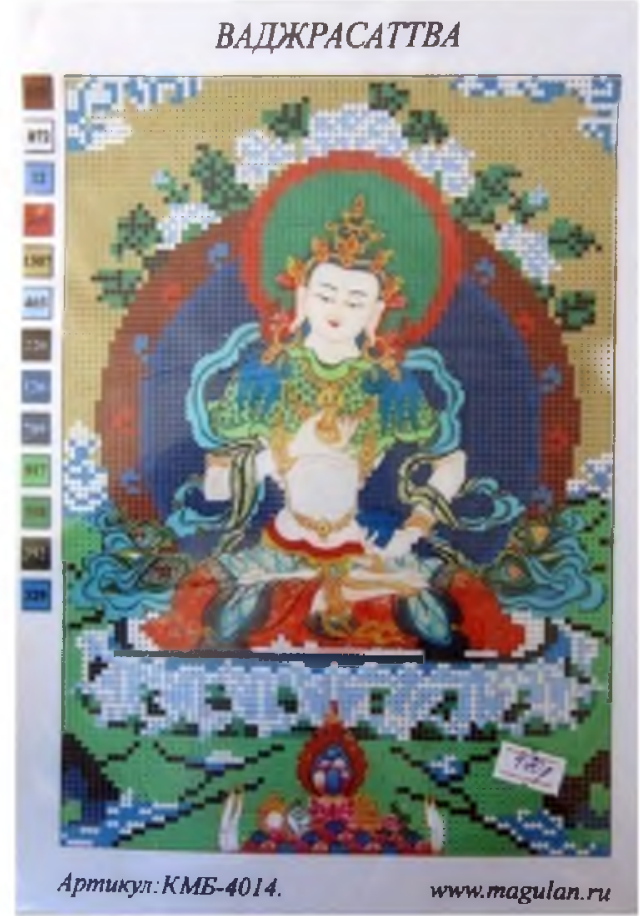

Pис. 10. Ваджрасаттва. Магазин «МеСаДе» в г. Элисте. Полная зашивка, габардин. Фото автора, г. Элиста. 2019 г.

[Fig. 10. Vajrasattva. Full embroidery kit, gabardine. MeSaDe retail store, Elista. Photo by author. 2019]

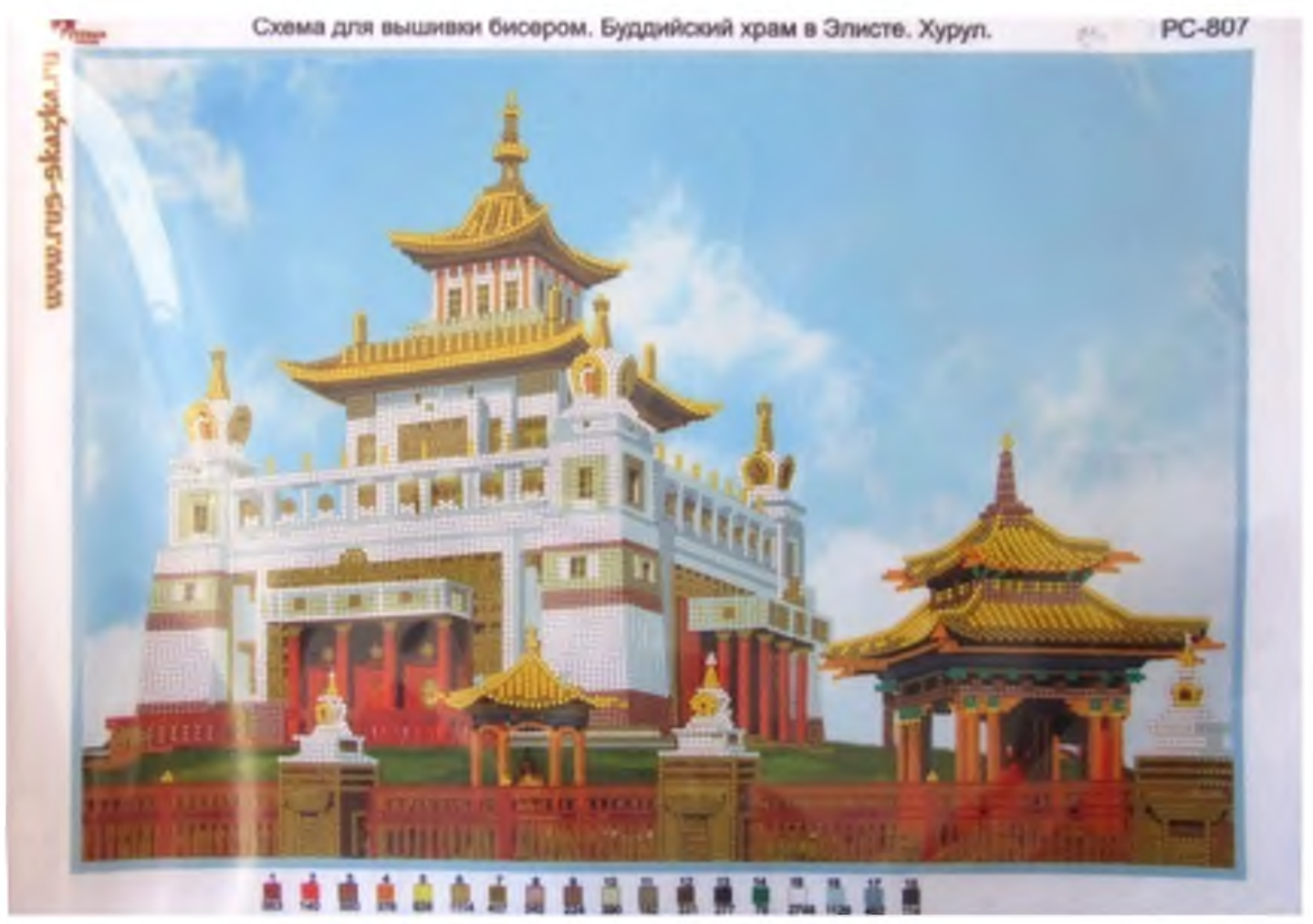

Puc. 11. Храм «Золотая обитель Будды Шакьямуни» (Бурхн-Багшин Алтн Сюме). Частичная зашивка, ткань - габардин

[Fig. 11. Golden Abode of Shakyamuni Buddha. Partial embroidery kit, fabric — gabardine] 


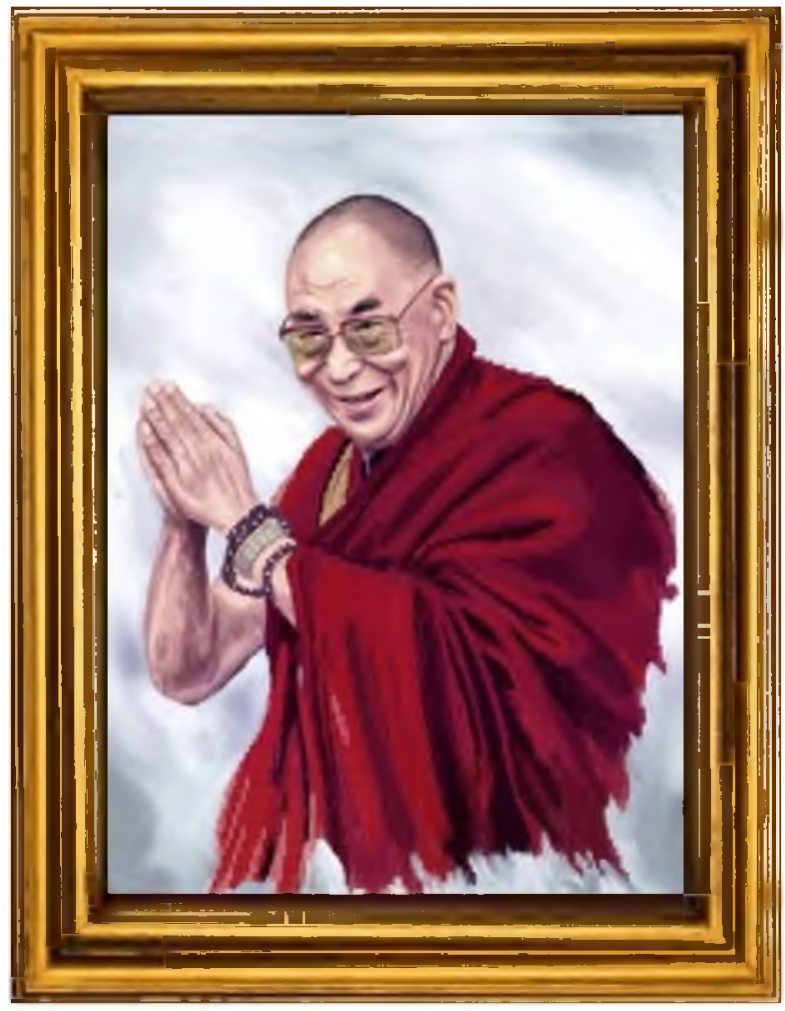

Puc. 12. Портрет Далай-ламы XIV. Основа для частичной вышивки, холст

[Fig. 12. Portrait of the $14^{\text {th }}$ Dalai Lama. Partial embroidery kit, canvas]

и холст в качестве основы. На схемах для частичной вышивки буддийские божества изображаются в соответствии с традиционными буддийскими танка путем оттиска рисунка на ткань (рис. 7).

Заинтересованность изготовления таких вышивок мастерицами основывается на сохранившихся образцах танка XIX в., которые встречаются в домах и храмах у калмыков. По данным исследователей, они имеют следующие композиционные схемы: с патронирующим образом над центральным персонажем и с четырьмя спутниками по углам; с ярусным расположением вокруг главного персонажа; пирамидальная композиция с главным персонажем в центре [Батырева 2005: 104], но лаконизм части изображаемых божеств, по мнению мастериц, в большей степени соответствует хранимым на семейных алтарях у калмыков (рис. 8, 9).

Сосуществование различных изображений божеств буддийского пантеона у калмыков, по нашему мнению, является наследием танкописи XIX и начала XX в., когда на основе общепринятых канонов калмыцкие иконописцы вырабатывали свою этноспецифическую линию.
В отличие от частичной полная зашивка основы бисером усложняет выделение элементов изображения божества и не позволяет учесть все нюансы рисунка, тем не менее, на такие основы также существует спрос у мастериц, что определяется небольшой стоимостью и наличием напечатанного изображения самого буддийского божества (рис. 10).

Одним из новшеств, введенных недавно, стало распространение основ для вышивки бисером с частичной зашивкой $c$ изображением буддийского храма «Золотой обители Будды Шакьямуни» (Бурхн-Багшин Алтн Сюме) (рис. 11) и Его Святейшества Далай-ламы XIV (рис. 12). Если вышивка храма является для мастериц обычно чисто коммерческим проектом, то портрет Далай-ламы XIV изготавливается для украшения семейного алтаря, жилища, подарка близким. Исследователи отмечали выделение в конце XIX - начале XX в. линии развития живописи буддийских иконописцев - портретные изображения лам «как вариантное воплощение канона» [Батырева 2005: 88], поэтому новшество в какой-то мере является продолжением традиции. 
Работ по изготовлению изображений буддийских божеств в технике гладьевого шитья и аппликации - все еше небольшое количество, они не столь популярны среди мастериц. Наборы для вышивания в технике гладьевого шитья изображений божеств буддийского пантеона все еще изготавливают только производители в Китае, но у калмыцких мастериц спрос на них значительно снизился. Желающие изготовить танка в этой технике предпочитают копировать изображение «калмыцкого» божества на тканевую основу, самостоятельно подбирать цвет и определять количество нитей.

Традиционная техника аппликации зегт нәәмл изготовления калмыцких танка сложна в исполнении, техника изготовления плетеных шнуров и тесьмы, изготавливавшихся мастерицами во время работы, не реконструирована. Но попытки реконструкции танка в такой технике была предприняты. Например, педагог-технолог и мастер-прикладник из п. Цаган-Аман Юстинского района Республики Калмыкия Н. Леджанова выполнила копию старинной танка с изображением основателя школы Гелуг Цзонкапы в этой технике. Совместно с заинтересовавшимися этой техникой мастерицами она пытается теперь возродить старинную калмыцкую технику изготовления танка.

Вышитые для продажи и в качестве подарка работы мастерицы оформляют в местных багетных мастерских, специальных буддийских ритуалов не проводят - считается, что такую танка должен «оживить» тот, в чьем доме она будет находиться. Такие танка приобретаются и как сувениры, поэтому возможно, что они могут использоваться туристами в доме просто как красивый атрибут в интерьере жилища.

Совершенно другой подход применяется мастерицами, если вышитую танка планируют разместить на алтаре дома или у близких. Сначала по дате и часу рождения человека определяют божество-покровителя, затем в магазинах для рукоделия подбирают набор или основу для вышивки, сопоставляя калмыцкий вариант наименования буддийского божества с общепринятыми, потому что «буддийские божества получили „калмыцкие имена, адаптированные мирянами, и свое цветовое обозначение» [Шараева 2017в: 192-193]. Так, Зеленая
Тара именуется Ноһан Дәрк (зеленый цвет), Авалокитешвара - Арьябала (светло-желтый), Майтрея - Мәәдр (бирюзовый, сине-зеленый), Акшобхья - Чакчва (синий), Амитаба - Аюка, Авьдв (красный), Ваджрасаттва - Дорж⿻ Сенбе (синий) и т. д. Цветовое обозначение божества важно при выборе хадака-подношения, который располагают («надевают») на готовой танка. Во многих магазинах, торгующих материалами для творчества, сейчас можно увидеть на прилавках листы, где напечатаны наименования божеств согласно общей буддийской традиции и калмыцкому эквиваленту. Продавцы всегда могут дать дополнительно подробные пояснения о каждом персонаже буддийского пантеона, их классификации и функциях, описать присущий им набор обязательных признаков в силу заинтересованности мастериц получить как можно больше сведений обо всем этом перед началом работы. Кроме того, стоит отметить, что современные мастерицы пытаются все же самостоятельно или при посещении буддийского храма усвоить такую информацию.

Выработался определенный набор правил, которым следуют современные мастерицы во время своей работы:

1) перед началом работы необходимо посетить буддийский храм (хурл) и принять участие в молебне;

2) начинают вышивку на растущей луне;

3) подходящий день начала вышивки подбирается по лунному календарю (если нет возможности приступить к работе сразу, то достаточно сделать пару стежков, главное - (нначать));

4) место для выполнения работы всегда должно быть чистым;

5) перед началом работы обязательно тщательно моют руки и полоскают рот;

6) выполняя вышивку, нежелательно отвлекаться на разговоры;

7) необходимо периодически произносить мантру божества, изображение которого выполняется; после завершения работы - посвящать заслуги прочитанных мантр на благо всех живых существ;

8) за день до начала и до окончания работы желательно придерживаться растительно-молочной пищи, воздержаться от посещения увеселительных мероприятий, 
мест большого скопления людей и воздержаться близости;

9) на обратной стороне работы нить узлом не закрепляют: считается, что обратная сторона «обращена к богу»;

10) по окончании работы принять участие в молебне и освятить ее у буддийского священнослужителя для «оживления» божества.

В основах для вышивки бисером лики божеств и некоторые части тела нанесены путем оттиска изображения. Это коррелирует с представлением, что лики божеств вышивать нежелательно. В наборах и основах в технике вышивки крестом и гладью мастерицы придерживаются иных правил: вышивку и оформление глаз божества оставляют на завершающий этап работы. Согласно сложившемуся правилу, необходимо с работой принять участие в молитве, санкционирующей это действие, затем выполнить работу и снова посетить молебен для проведения ритуала «открывания глаз». Готовые работы оформляют в виде свитка или под стекло в рамку.

\section{Результаты и вывод}

В процессе своего развития буддизм в Калмыкии сформировал свои этноспецифические черты, которые нашли отражение в повседневных и храмовых практиках, предметах религиозного культа, духовной и обрядовой сферах. Особую нишу в культовой сфере калмыков занимают танка с изображением буддийских божеств, выполненных в разных техниках. Все буддийские божества у калмыков имеют калмыцкие названия, существуют устойчивые представления о соответствующем им цвете. Отличительными чертами изображений божеств у калмыков являются: отсутствие пышного и яркого оформления пространства вокруг божества, лаконичность красок и отсутствие полутонов, разграничение фона с выделением преимущественно голубым или синим цветом неба, зеленым - жизненного пространства, небольшое количество растительности, где преобладают полураскрытые тюльпаны различного окраса или цветы похожие на них, обязательное обозначение луны и солнца, к которым направлены вытянутые края слоисто-кучевых облаков, сходство черт лика божеств с антропологическим типом калмыков, характерным для представителей центральноазиатского типа монголоидной расы (выделяют плоское лицо, высокое переносье и приплюснутый нос с широкими ноздрями, узкие глаза, большие и вытянутые уши).

Распространяющаяся среди калмычек-мирян практика изготовления вышитых изображений божеств буддийского пантеона отражает двойственность процесса: с одной стороны, изготовление танка в вышивке как образцов культового декоративно-прикладного искусства калмыков не противоречит традиции, с другой стороны - является и попыткой реконструкции изготовления танка посредством приемов вышивки с использованием различных материалов, и новым видом женского рукоделия. В традиционных практиках танка изготавливали в двух техниках — аппликативной и глади. В первой - по краям лоскута шелковых тканей использовался прием наложения шнура для выделения контура, во второй - выделение контуров происходило за счет самой вышиваемой глади. В современных вышивках буддийских божеств сочетаются различные виды и техники - вышивка крестом, бисером, гладью, аппликация; частичная и полная вышивка; вышивка на напечатанной и чистой основе. Современные калмычки-мастерицы предпочитают в технике вышивки создавать копии старинных калмыцких танка или выбирают из широкого ассортимента различных производителей наборы и основы для вышивки, в которых, по их мнению, изображение божеств имеет сходные черты с антропологическим типом калмыков, или в целом сходство с изображением на старинных калмыцких танка. Кроме того, при выполнении работ мастерицы придерживаются определенных правил, например, принятие обетов на период работы, обязательное чтение молитв, согласование начала работы по лунному календарю, вышивка глаз божества на завершающем этапе, предваряемом чтение специальной молитвы для «открывания глаз», совершение подношений в храме по окончании работ и участие в молебне по «оживлению» изготовленного божества. Все это в совокупности указывает, что, несмотря на изменение техник и материалов, в вышивке буддийских божеств калмычками-мастерицами сохраняются традиционные практики. 


\section{Литература}

Бакаева 1994 - Бакаева Э. П. Буддизм в Калмыкии. Историко-этнографические очерки. Элиста: Калм. кн. изд-во, 1994. 128 с.

Бакаева 2009 - Бакаева Э. П. Буддизм в Калмыкии: основные этапы истории // Буддизм в России. 2009. № 42. С. 9-17.

Басхаев 2007 - Басхаев A. Н. Буддийская церковь Калмыкии: 1900-1943 гг. Элиста: НГП «Джангар», 2007. 240 с.

Батырева 1991 - Батырева С. Г. Старокалмыцкое искусство: Альбом. Элиста: Калм. кн. изд-во, 1991. 127 с., 102 илл.

Батырева 2005 - Батырева С. Г. Старокалмыцкое искусство XVII - начало XX вв. М.: Наука, 2005. 155 с.

Белый старец 2020 - Калмыцкая икона Белого старца [электронный ресурс] // Из фондов Новочеркасского музея донского казачества. Соцсеть «В контакте». Моя Калмыкия. 14 июня 2020 г. URL: https://vk.com/ wall-185326518 8614 (дата обрашения: 10.12.2020).

Бодхисаттва Манджушри - Бодхисаттва Манджушри [электронный ресурс] // Абхидхарма Чой. URL: http://abhidharma.ru/A/ Bodhissatva/Manjushri.htm (дата обращения: 19.12.2020).

Буддийскую святыню 2019 - Буддийскую святыню «Зеленую Тару» привезли в столицу Калмыкии из Ставрополя [электронный ресурс] // ТACC. 05.10.2019. https:// tass.ru/obschestvo/6967330 (дата обращения: 15.12.2020).

В Калмыкии открылась 2019 - В Калмыкии открылась выставка «Зеленая Тара» (Фоторепортаж) [электронный ресурс] // РИА «Калмыкия». Новости. 08.10.2019 // https:// riakalm.ru/index.php/news/news/20438monakhi-tsentralnogo-khurula-osvyatili-tankuzelenaya-tara (дата обращения: 19.12.2020).

Выставка 2016 - Выставка «Старинные танки - наследие наших предков» [электронный ресурс] // Инф. портал «В Калмыкии». 29.02.2016. URL: https://vkalmykii.com/ vystavka-starinnye-tanki-nasledie-nashikhpredkov (дата обращения: 20.12.2020).

Дорджиева 1995 - Дорджиева Г. ШІ. Буддизм и христианство в Калмыкии. Опыт анализа религиозной политики правительства Российской империи (середина XVII - начало XX вв.). Элиста: АГІІІ «Джангар», 1995. $128 \mathrm{c}$.

Житецкий 1893 - Житецкий И. А. Очерки быта астраханских калмыков (этнографические наблюдения 1884-1886 гг.). М.: Тип. М. Г. Волчанинова, 1893.87 с.
Житецкий 1892 - Житечкий Н. А. Астраханские калмыки (наблюдения и заметки): в двух очерках // Сборник трудов членов Петровского общества исследователей Астраханского края. Астрахань: Тип. «Астраханского листка», 1892. С. 1-V, 1-214.

Зеленая Тара 1992 - Зеленая Тара / вст. статья И. Г. Ковалева, Т. Ц.-У. Бембееевой. Элиста: Калм. гос. картин. галерея, 1992. 32 ил.

Иванов 2009 - Иванов Д. В. Калмыцкие буддийские предметы в коллекциях Музея археологии и этнографии РАН (Кунсткамера) // Буддизм в России. 2009. № 4. С. 28-32.

Иванов 2008 - Иванов Д. В. Калмыцкие иконы в коллекциях МАЭ (Кунсткамера) РАН: характерные особенности иконографии и монтировки // Кюнеровский сборник: Материалы Восточноазиатских и Юго-Восточных исследований. СПб.: МАЭ РАН, 2008. Вып.5. С. 51-52.

История буддизма 2011 - История буддизма в СССР и Российской Федерации в 19851999 гг. / отв. ред. Н. Г. Очирова. Элиста: Мин-во образования, культуры и науки Республики Калмыкия, 2011. 392 с.: ил

КРС 1977 - Калмыцко-русский словарь / под ред. Б. Д. Муниева. М.: Русский язык, 1977. $764 \mathrm{c}$.

Курапов 2018 - Курапов A. A. Российское государство и буддийская церковь на юге России: этапы эволюции социально-политического взаимодействия в XVII - начале $\mathrm{XX}$ вв. Астрахань: Изд. Сорокин Роман Васильевич, 2018. 464 с.

Львовский 1898 - Львовский $Н$. Калмыки Большедербетовского улуса Ставропольской губернии и калмыцкие хурулы. 2-е изд. Ставрополь: Типо-лит. Т. М. Тимофеева, 1898. $173 \mathrm{c}$.

Монголо-ойратские законы 1880 - Монголо-ойратские законы 1640 года, дополнительные указы Галдан-Хун-Тайджия и законы, составленные для волжских калмыков при калмыцком хане Дондук-Даши / калм. текст с рус. пер. и прим. К. Ф. Голстунского. СПб.: тип. Имп. Акад. наук, 1880. 16, 143. [1] c.

Монгуш 2015 - Монгуш Е. Д. Буддийские храмы как объекты религиозного туризма в России // Новые исследования Тувы. 2015. № 3. C. 101-110

Музраева 2012 - Музраева Д. Н. Буддийские письменные источники на тибетском и ойратском языках в коллекциях Калмыкии. Элиста: НПП «Джангар», 2012. 224 с.

Мучаева 2003 - Мучаева $И$. И. Памятники буддийского культа в Калмыкии: проблемы 
сохранения и использования // Вестник Калмыцкого республиканского краеведческого музея им. Н. Н. Пальмова. Элиста, 2003 Вып. 1. С. 31-38.

Небольсин 1852 - Небольсин П. И. Очерки быта калмыков Хошеутовского улуса. СПб.: Тип. Карла Крайя, 1852. 192 с.

Нурова 2007 - Нурова Г. В. Образ женского божества в буддизме Махаяны // Вестник Института комплексных исследований аридных территорий. 2007. Т. 2. № 2 (15). C. $155-160$.

Огнева 1992 - Огнева Е. Д. Танка // Буддизм: словарь. М.: Республика, 1992. С. 236-237.

Открытие выставки 2020 - Открытие выставки «15 чудес Будды Шакьямуни» [электронный ресурс] // Центральный хурул РК «Золотая обитель Будды Шакьямуни». Новости. 25.02.2020. URL: http://www. khurul.ru/2020/02/25/otkrytie-vystavki-15chudes-buddy-shakyamuni/ (дата обращения: 15.12.2020).

Руднев $1905-$ Руднев A. Д. Заметки о технике буддийской иконографии у современных зурачинов Урги, Забайкалья и Астраханской губернии // Сборник МАЭ. СПб.: Тип. Имп. акад.наук, 1905. Вып. 5. 16 с

Туристический путеводитель - Туристический путеводитель по городу Элисте [электронный ресурс] // Персональный сайт о путе-

\section{References}

Bakaeva E. P. Buddhism in Kalmykia: Historical and Ethnographic Essays. Elista: Kalmyk Book Publ., 1994. 128 p. (In Russ.)

Bakaeva E. P. Buddhism in Kalmykia: key historical stages. Buddhism of Russia. 2009. No. 42. Pp. 9-17. (In Russ.)

Baskhaev A. N. Buddhist Church of Kalmykia: 1900-1943. Elista: Dzhangar, 2007. 240 p. (In Russ.)

Batyreva S. G. Old Kalmyk Arts. Album. Elista: Kalmyk Book Publ., 1991. 127 p. (In Russ.)

Batyreva S. G. Old Kalmyk Arts: $17^{\text {th }}-$ Early $20^{\text {th }}$ Centuries. Kalmyk Humanities Research Institute (RAS). Moscow: Nauka, 2005. 155 p. (In Russ.)

Bodhisattva Manjushri. On: Abhidharma Chos. Available at: http://abhidharma.ru/A/ Bodhissatva/Manjushri.htm (accessed: December 19, 2020). (In Russ.)

Buddhist Statue of Green Tara Delivered to Kalmykia's Capital from Stavropol. On: Russian News Agency (TASS; website). Posted on October 5, 2019. https://tass.ru/ шествиях и поездках по миру. URL: http:// www.capone-online.ru/volga_guide_elista. html (дата обращения: 19.12.2020).

Цаган Аав 1801-1925 - Цаган Аав, Белый старец [электронный ресурс] // Собрание Музея калмыцкой традиционной культуры имени Зая-Пандиты КалмНЦ (КИГИ) РАН. Инв. № И-45.

Шараева 2017 a - Нараева Т. И. Образы божеств в декоративно-прикладном искусстве калмыков: Зеленая Тара // Вестник Калмыцкого института гуманитарных исследований РАН. 2017. № 3 (31). С. 84-92. DOI: 10.22162/2075-7794-2017-31-3-84-92

Шараева 20176 - Шараева T. И. Сувенирная продукция и развитие туризма (на примере этнического предпринимательства мастеров народных ремесел Калмыкии) // Монголоведение. 2017. № 11. С. 70-80. DOI: DOI 10.22162/2500-1523-2017-11-70-80

Шараева 2017в - Нараева Т. И. Этнические маркеры калмыков: исследование и материалы. Элиста: КалмНЦ РАН, 2017. 288 с.

Эрендженова 2014 - Эрендженова В. О калмыцких реликвиях и общественном фонде «Наследие» // Элистинская панорама. 20.10.2014 [электронный ресурс] // http:// buddhist.ru/buddhist-new s/site/6533-okalmyckih-relikviiah-i-obshe (дата обращения: 17.12.2020).

obschestvo/6967330 (accessed: December 15 , 2020). (In Russ.)

Dordzhieva G. Sh. Buddhism and Christianity in Kalmykia: Analysis of Russian Imperial Religious Policies, Mid-17 $7^{\text {th }}-$ Early $20^{\text {th }}$ Centuries. Elista: Dzhangar, 1995. 128 p. (In Russ.)

Erendzhenova V. About Kalmyk relics and Nasledie non-governmental foundation. On: Elistinskaya Panorama newspaper website. Posted on October 20, 2014. Available at: http://buddhist. ru/buddhist-new s/site/6533-o-kalmy ckihrelikviiah-i-obshe (accessed: December 17, 2020). (In Russ.)

Exhibition 'Old Thangkas - Heritage of Our Ancestors'. On: V Kalmykii online news outlet. Posted on February 29, 2016. Available at: https://vkalmykii.com/vystavka-starinnyetanki-nasledie-nashikh-predkov (accessed: December 20, 2020). (In Russ.)

Exhibition of Green Tara Opened in Kalmykia (photographic report). On: Kalmykia Republican News Agency. Newsfeed. Posted on October 8, 2019. Available at: https://riakalm. 
ru/index.php/news/news/20438-monakhitsentralnogo-khurula-osvyatili-tanku-zelenayatara (accessed: December 19, 2020). (In Russ.)

Green Tara. I. Kovalev, T. Bembeeva (foreword). Elista: Kalmyk State Picture Gallery, 1992. 32 p. (In Russ.)

Ivanov D. V. Kalmyk Buddhist attributes stored at Peter the Great Museum of Anthropology and Ethnography (Kunstkamera). Buddhism of Russia. 2009. No. 4. Pp. 28-32. (In Russ.)

Ivanov D. V. Kalmyk thangkas stored at Peter the Great Museum of Anthropology and Ethnography (Kunstkamera): iconographic and structural features. In: The Kuehner Collection. Materials of East Asian and Southeastern Studies. St. Petersburg: Museum of Anthropology and Ethnography (RAS), 2008. Vol. 5. Pp. 51-52. (In Russ.)

Kurapov A. A. Russian Government and Buddhist Church in Southern Russia: Evolutionary Stages of Sociopolitical Interaction, $17^{\text {th }}-$ Early $20^{\text {th }}$ Centuries. Astrakhan: R. Sorokin, 2018. 464 p. (In Russ.)

Lvovsky N. Kalmyks of Bolshederbetovsky District (Stavropol Governorate) and Kalmyk Buddhist Temples. $2^{\text {nd }}$ ed. Stavropol: T. Timofeev, 1898. 173 p. (In Russ.)

Mongush E. D. Buddhist temples as a religious tourism objects in Russia. The New Research of Tuva. 2015. No. 3. Pp. 101-110. (In Russ.)

Muchaeva I. I. Buddhist monuments in Kalmykia: problems of preservation and use. Vestnik Kalmytskogo respublikanskogo kraevedcheskogo muzeya im. N. N. Pal'mova. 2003. No. 1. Pp. 31-38. (In Russ.)

Muniev B. D. (ed.) Kalmyk-Russian Dictionary. Moscow: Russkiy Yazyk, 1977. 764 p. (In Kalm. and Russ.)

Muzraeva D. N. Tibetan- and Oirat-Language Buddhist Written Sources in Kalmykia's Collections. Elista: Dzhangar, 2012. 224 p. (In Russ.)

Nebolsin P. I. Kalmyks of Khosheutovsky District: Sketches of Everyday Life. St. Petersburg: K. Kray, 1852. 192 p. (In Russ.)

Nurova G. V. Images of female deities in Mahayana Buddhism. Vestnik Instituta kompleksnykh issledovaniy aridnykh territoriy. 2007. Vol. 2. No. 2 (15). Pp. 155-160. (In Russ.)

Ochirova N. G. (ed.) History of Buddhism in the USSR and Russian Federation: 1985-1999. Elista: Ministry of Education, Culture and Science of Kalmykia, 2011. 392 p. (In Russ.)

Ogneva E. D. Thangka. In: A Dictionary Buddhism. Moscow: Respublika, 1992. Pp. 236-237. (In Russ.)

Oirat-Mongolian Laws of 1640, Supplemented with Edicts of Galdan Hong Tayiji, Compiled for the
Volga Kalmyks during the Reign of Khan Donduk-Dashi. K. Golstunsky (Kalm. text, transl., etc.). St. Petersburg: Imperial Academy of Sciences, 1880. 16, 143 p. (In Kalm. and Russ.)

Opening of Exhibition 'Fifteen Miracles of Shakyamuni Buddha'. On: Central Buddhist Temple (Khurul) 'Golden Abode of Shakyamuni Buddha' (website). Newsfeed. Posted on February 25, 2020. Available at: http:// www.khurul.ru/2020/02/25/otkrytie-vystavki-15-chudes-buddy-shakyamuni/ (accessed: December 15, 2020). (In Russ.)

Rudnev A. D. Contemporary thangka painters of Urga, Transbaikalia, and Astrakhan Governorate: notes on Buddhist iconographic techniques. Sbornik MAE. 1905. Vol. 5. 16 p. (In Russ.)

Sharaeva T. I. Ethnic Markers of the Kalmyks: Study and Materials. Elista: Kalmyk Scientific Center (RAS), 2017. 288 p. (In Russ.)

Sharaeva T. I. Images of deities in decorative and applied arts of the Kalmyks: Green Tara. Bulletin of the Kalmyk Institute for Humanities of the RAS (Oriental Studies-Elista). 2017. No. 3 (31). Pp. 84-92. (In Russ.) DOI: 10.22162/20757794-2017-31-3-84-92

Sharaeva T. I. Souvenir products and tourism development (evidence from ethnic entrepreneurial activities of Kalmykia's folk craftsmen). Mongolian Studies. 2017. No. 11. Pp. 70-80. (In Russ.) DOI: DOI 10.22162/2500-1523-201711-70-80

Thangka of the White Old Man (stored at Don Cossack Museum of Novocherkassk). On: VK social networking service. Moya Kalmykiya (group). Posted on June 14, 2020. Available at: https://vk.com/wall-185326518_8614 (accessed: December 10, 2020). (In Russ.)

Tourist Guidebook to Elista. On: Personal Travel Accounts Online. Available at: http:/www. capone-online.ru/volga_guide_elista.html (accessed: December 19, 2020). (In Russ.)

Tsagan Aav, the White Old Man. On: Zaya Pandita Museum of Kalmyk Traditional Culture (website), Kalmyk Scientific Center (RAS). Inv. no. И-45. Available at: http://biliq.ru/museum/ exh/2576 (accessed: December 18, 2020). (In Russ.)

Zhitetsky I. A. Astrakhan Kalmyks (observations and notes): two essays. In: Collected Works by Members of Peter the Great Society for the Study of Astrakhan Lands. Astrakhan: Astrakhanskiy Listok, 1892. Pp. 1-V, 1-214. (In Russ.)

Zhitetsky I. A. Astrakhan Kalmyks: Sketches of Everyday Life. Ethnographic Observations of 1884-1886. Moscow: M. Volchaninov, 1893. 87 p. (In Russ.) 